\title{
La aplicación de los Convenios de Ginebra en ausencia de un conflicto armado: El caso de la dictadura militar chilena ${ }^{\left.(*)()^{(*)}\right)}$
}

\author{
The application of the Geneva Conventions in the absence of an armed \\ conflict: The case of the Chilean military dictatorship
}

\author{
Catalina Fernández Carter ${ }^{(* *)}$ \\ Universidad de Chile (Santiago de Chile, Chile)
}

\begin{abstract}
Resumen: Este artículo examina las decisiones de la Corte Suprema chilena, que ha invocado y aplicado los Convenios de Ginebra a los hechos ocurridos durante la dictadura militar chilena que tuvo lugar entre 1973 y 1990. Como se explicará, dichas normas internacionales han permitido a la Corte dejar sin efecto las normas de amnistía dictadas por el régimen militar y no considerar la prescripción penal de los crímenes de encarcelamiento, tortura, asesinato y desaparición forzada, entre otros. Lo peculiar, sin embargo, es que la Corte Suprema ha pasado por alto los supuestos de aplicación del Derecho Internacional Humanitario, y se ha basado casi exclusivamente en la declaración de guerra dictada por la Junta de Gobierno en los primeros días de la dictadura. Ello le ha permitido dar una aplicación extensiva al Derecho Internacional Humanitario, que hace caso omiso a sus elementos fundamentales, incluyendo la distinción entre conflictos armados internacionales y no internacionales. En ese contexto, este trabajo cuestiona dicho razonamiento, exponiendo los riesgos que el mismo supone, y evidenciando la existencia de un régimen jurídico alternativo -el Derecho Internacional de los Derechos Humanos- que no solo otorga mayor protección, sino que además refleja adecuadamente la realidad de los hechos ocurridos durante la dictadura, y el abuso y violencia estatal del que fue víctima la población chilena, sin resistencia.
\end{abstract}

Palabras clave: Derecho Internacional Humanitario - Convenios de Ginebra - Artículo 3 común - Dictadura militar chilena - Crímenes de lesa humanidad

\begin{abstract}
This article examines the decisions of the Chilean Supreme Court, which has invoked and applied the Geneva Conventions to the events that occurred during the Chilean military dictatorship that took place between 1973 and 1990. As will be explained, these norms have allowed the Court to render ineffective the amnesty dictated by the military regime and to disregard the statute of limitations for the crimes of imprisonment, torture, murder and forced disappearance, among others. Notably, however, the Supreme Court has overlooked the requirements for the application of international humanitarian law, and has relied almost exclusively on the declaration of war issued by the Junta de Gobierno in the early days of the dictatorship. This has allowed the Court to provide for an extensive application of international humanitarian law, which ignores its fundamental elements, including the distinction between international and non-international armed conflicts. In this context, this paper questions this reasoning, exposes the risks it entails,
\end{abstract}

(*) Nota del Equipo Editorial: Este artículo fue recibido el 10 de setiembre de 2021 y su publicación fue aprobada el 11 de octubre de 2021.

${ }^{* *}$ La autora desea agradecer a Valentina Gómez Baltán, Aracelli Torrejón Gómez y Maite Fuenzalida Espinosa por su asistencia para la elaboración de este trabajo.

$\left(^{* * *}\right)$ Abogada de la Universidad de Chile (Santiago, Chile) y Magíster en Derecho Internacional de la Universidad de Cambridge (Cambridge, Reino Unido). Académica Instructora de la Facultad de Derecho de la Universidad de Chile. ORCID: http://orcid.org/0000-0002-69223910. Correo electrónico: cfernandez@derecho.uchile.cl. 
La aplicación de los Convenios de Ginebra en ausencia de un conflicto armado: El caso de la dictadura militar chilena

The application of the Geneva Conventions in the absence of an armed conflict: The case of the Chilean military dictatorship

and demonstrates the existence of an alternative legal regime -international human rights law- that not only provides greater protection, but also adequately reflects the reality of the events that took place during the dictatorship, and the abuse and state violence to which the Chilean population fell victim, without resistance.

Keywords: International Humanitarian Law - Geneva Conventions - Common article 3 - Chilean military dictatorship - Crimes against humanity

\section{Introducción}

Entre el 11 de setiembre de 1973 y el 11 de marzo de 1990, Chile estuvo sometido a un régimen dictatorial, liderado por el General Augusto Pinochet Ugarte, que resultó en el encarcelamiento, tortura, muerte y desaparición forzada de decenas de miles de personas que se oponían a las autoridades civiles y militares al mando del país ${ }^{(1)}$.

Desde sus primeros días, la dictadura militar chilena intentó esconder sus acciones bajo un manto de legalidad, y se valió de una serie de herramientas jurídicas para justificar su conducta, los actos de violencia de sus agentes, y sus transgresiones permanentes a garantías básicas en materia de derechos fundamentales. Así, una de las primeras iniciativas del régimen de facto fue la aprobación del Decreto Ley 3 de 11 de setiembre de $1973^{(2)}$, por medio del cual la Junta de Gobierno declaró Estado de Sitio en todo el territorio de la República. Dicho Decreto Ley consideraba como antecedente "la situación de conmoción interior que vive el país". El día siguiente, la dictadura militar adoptó el Decreto Ley $5^{(3)}$, por medio del cual declaró que el Estado de Sitio decretado por conmoción interna y establecido por medio del Decreto Ley 3 debía entenderse como un "estado o tiempo de guerra", que hacía aplicable el Código de Justicia Militar y reconocía la jurisdicción de los tribunales militares para conocer de ciertos delitos.

Un tiempo después, mediante la adopción del Decreto Ley 640 de 2 de setiembre de $1974^{(4)}$, se complementó la regulación impuesta en los anteriores decretos, indicando que "[e]n los casos en que se declare el Estado de Sitio por Situación de Guerra Interna o Externa [...] entrarán en funcionamiento los Tribunales Militares de tiempo de guerra a que se refiere el Título III del Libro I del Código de Justicia Militar, con la jurisdicción militar de ese tiempo y se aplicará el procedimiento establecido en el Título IV del Libro II de dicho Código y la penalidad especialmente prevista para tiempo de guerra". Finalmente, el 18 de abril de 1978, la dictadura militar adoptó el Decreto Ley $2191^{(5)}$, que concedió una amnistía a todas las personas que hubieran cometido hechos delictivos entre el 11 de setiembre de 1973 y el 10 de marzo de 1978 (en adelante, el "Decreto Ley de Amnistía").

Una vez reinstaurada la democracia en Chile, a partir del 11 de marzo de 1990, las víctimas de violencia estatal comenzaron a presentar una serie de acciones ante los tribunales chilenos, para hacer efectiva la responsabilidad de los autores de dichos crímenes. En una primera etapa, los tribunales de justicia consideraron que la adopción del Decreto Ley de Amnistía, sumada a la prescripción de la acción penal -atendido el tiempo transcurrido desde la comisión de los delitos-, hacía imposible el juzgamiento de los responsables (Díaz Tolosa, 2006). Sin embargo, a mediados de la década del 2000, la Corte Suprema comenzó a invocar la normativa del Derecho Internacional Humanitario y del Derecho Internacional de los Derechos Humanos para dejar sin efecto la amnistía y no considerar la prescripción, permitiendo así el juzgamiento de los individuos responsables por estos crímenes.

(1) En primer lugar, la Comisión Nacional de Verdad y Reconciliación reconoció a 2,296 personas como víctimas de violaciones a los derechos humanos, enfocándose principalmente en las personas que habían sido asesinadas y detenidas o desaparecidas por agentes estatales o por personas a su servicio (Comisión Nacional de Verdad y Reconciliación, 1996). Posteriormente, la Comisión Nacional de Reparación y Reconciliación agregó 899 casos (Corporación Nacional de Reparación y Reconciliación, 1996). Por otra parte, el Informe de la Comisión Valech I reconoció a 27,255 personas como víctimas de prisión política y tortura (Comisión Nacional sobre Prisión Política y Tortura, 2004), agregando otros 1,204 casos en su etapa de reconsideración (Comisión Nacional sobre Prisión Política y Tortura, 2005). Luego, la Comisión Valech II reconoció otros 30 casos Rettig y 9,795 casos Valech (Comisión Presidencial Asesora para la Calificación de Detenidos Desaparecidos, Ejecutados Políticos y Víctimas de Prisión Política y Tortura, 2011).

(2) Este Decreto Ley fue publicado en el Diario Oficial el 18 de septiembre de 1973.

(3) Este Decreto Ley fue publicado en el Diario Oficial el 22 de septiembre de 1973.

(4) Este Decreto Ley fue publicado en el Diario Oficial el 10 de septiembre de 1974.

(5) Este Decreto Ley fue publicado en el Diario Oficial el 19 de abril de 1978. 
Este artículo busca examinar críticamente las decisiones de la Corte Suprema, sobre todo en lo que respecta a la utilización de los cuatro Convenios de Ginebra de 1949 como derecho aplicable a la situación chilena durante la dictadura militar. Para ello, este trabajo comienza describiendo los aspectos generales del Derecho Internacional Humanitario y su presupuesto de aplicación -la existencia de un conflicto armado-, para luego examinar la situación chilena y determinar preliminarmente si existían elementos que permitieran verificar tal conflicto armado en Chile. Tras ello, el artículo revisa la jurisprudencia de la Corte Suprema chilena, constatando que la Corte ignoró los supuestos de aplicación del Derecho Internacional Humanitario, y lo homologó impropiamente con el régimen del Derecho Internacional de los Derechos Humanos, exponiendo algunas de sus decisiones más problemáticas. Finalmente, el artículo explica que existen alternativas al camino seguido por la Corte Suprema, que sean respetuosas del régimen legal internacional y que además reflejan adecuadamente la situación fáctica que tuvo lugar en Chile durante la dictadura militar, acudiendo al Derecho Internacional de los Derechos Humanos.

\section{El marco general del Derecho Internacional Humanitario}

El Derecho Internacional Humanitario es una rama del Derecho Internacional Público que establece las normas aplicables a los conflictos armados. El mismo se enfoca tanto en la protección de ciertas personas -en lo que tradicionalmente se denomina el "Derecho de Ginebra"- como en el desarrollo de las hostilidades, regulando medios y métodos de combate prohibidos -el llamado "Derecho de La Haya”- (Salmón, 2016).

El Derecho Humanitario tiene una larga data en el Derecho Internacional Público. En efecto, el primer tratado internacional adoptado en esta materia fue el Convenio de
Ginebra para el mejoramiento de la suerte de los militares heridos en los ejércitos en campaña, adoptado en 1864. Tras este, se han adoptado una serie de otros acuerdos internacionales que regulan los conflictos armados y que han ido ampliando y sofisticando la regulación internacional en esta materia(6). Un importante hito se logró en 1949 con la adopción de los cuatro Convenios de Ginebra, que fueron complementados en 1977 con la aprobación de sus dos Protocolos Adicionales $^{(7)}$. En paralelo, se adoptaron una serie de tratados específicos a la regulación o prohibición de ciertas armas y/o municiones ${ }^{(8)}$, la protección de la propiedad cultural ${ }^{(9)}$ y el resguardo del medio ambiente ${ }^{(10)}$. A estos importantes desarrollos en materia de tratados internacionales -que han llevado a sostener que el Derecho Internacional Humanitario es una de las áreas más codificadas del Derecho Internacional Público (Melzer, 2019)-, se suma un significativo desarrollo del internacional consuetudinario (Henckaerts \& Doswald-Beck, 2005).

Ahora bien, a diferencia de otras áreas del Derecho Internacional Público, el Derecho Internacional Humanitario tiene un ámbito específico de aplicación, que requiere la verificación de un presupuesto fáctico: la existencia de un conflicto armado. Sin conflicto armado, la mayor parte de la normativa convencional y consuetudinaria del Derecho Internacional Humanitario resulta inaplicable, con la excepción de unas pocas disposiciones que operan en tiempos de paz ${ }^{(11)}$.

(6) Entre ellos se incluyen la Declaración de La Haya prohibiendo el empleo de las balas que se hinchan o aplastan fácilmente en el cuerpo humano (1899); los Convenios derivados de las Conferencias de Paz de La Haya de 1899 y 1907; la Convención de Ginebra para mejorar la suerte de los heridos y enfermos (1906); el Protocolo contra el uso de gases (1925); las Convenciones de Ginebra sobre prisioneros de guerra y sobre la suerte de heridos y enfermos (1929), entre otros.

(7) En el año 2005 se adoptó el Protocolo III Adicional a los Convenios de Ginebra. Sin embargo, el mismo no regula normas relativas a la protección de personas ni a métodos y medios de combate prohibidos, sino que incorpora un signo distintivo adicional, el cristal rojo.

(8) Ello incluye la Convención sobre las Armas Biológicas (1972); la Convención sobre Armas Convencionales (1980) y sus protocolos; la Convención sobre las Armas Químicas (1993); la Convención sobre la prohibición de minas antipersonales (1997); la Convención sobre municiones en racimo (2008); el Tratado sobre la prohibición de las armas nucleares (2017), entre otros.

(9) Convención para la Protección de los Bienes Culturales en caso de conflicto armado (1954) y sus protocolos.

(10) Convención sobre la Prohibición del Uso de Técnicas de Modificación del Medio Ambiente con Fines Militares o con cualquier otro Fin Hostil (1977).

(11) Entre ellas se encuentran los artículos 49 del I Convenio, 50 del II Convenio, 129 del III Convenio y 146 del IV Convenio, que establecen deberes de adoptar medidas legislativas para establecer sanciones contra quienes cometan o den orden de cometer cualquiera de las infracciones graves establecidas en los respectivos Convenios. Véase igualmente artículos 47 del I Convenio, 48 del II Convenio, 127 del III Convenio y 144 del IV Convenio relativos a la obligación de difundir el texto de los Convenios de Ginebra. En materia de Derecho Internacional Consuetudinario, véase por ejemplo Normas 142 y 143 (Henckaerts \& Doswald-Beck, 2005). 
La aplicación de los Convenios de Ginebra en ausencia de un conflicto armado: El caso de la dictadura militar chilena

The application of the Geneva Conventions in the absence of an armed conflict: The case of the Chilean military dictatorship

Si bien no existe una única definición de qué es un conflicto armado, una de las definiciones más citadas es la adoptada por el Tribunal Penal Internacional para la ex Yugoslavia ("TPIY") en el caso Tadić (1995), que indicó que existe un conflicto armado "siempre que se recurra a la fuerza armada entre Estados o a la violencia armada prolongada entre autoridades gubernamentales y grupos armados organizados o entre dichos grupos dentro de un Estado" (párr. 70)(12). Esa definición permite además constatar la existencia de dos tipos de conflictos armados: Ios conflictos armados internacionales ("CAl") y los conflictos armados no internacionales ("CANI"). La distinción entre ambos tipos de conflictos armados es tan relevante, que suele ser una de las primeras materias que se enseñan al estudiante de Derecho Internacional Humanitario (Wilmshurst, 2012).

Los CAl se encuentran regulados en el artículo 2 común a los Convenios de Ginebra y el artículo 1(4) del Protocolo I Adicional a los Convenios de Ginebra, y abarcan tanto las hipótesis de guerra declarada, de conflicto interestatal, de ocupación total o parcial del territorio, y las guerras de liberación nacional(13). Este tipo de conflictos armados se encuentran regulados por la totalidad de los cuatro Convenios de Ginebra -de aplicación universal, habiendo sido ratificados por todos los Estados del mundo-, por las disposiciones del Protocolo I Adicional -para aquellos Estados que lo hayan ratificado-, y por un gran número de normas de carácter consuetudinario ${ }^{(14)}$.

En cambio, la regulación aplicable a los CANI es significativamente más reducida. Como indica Melzer (2019), "el [Derecho Internacional Humanitario] Convencional que se aplica en los conflictos armados no internacionales está mucho menos desarrollado" (p. 21). En efecto, los diversos tratados en materia de Derecho Humanitario que fueron adoptados desde 1864 no se aplicaban a los CANI, encontrándose delimitados exclusivamente a los conflictos internacionales. Los primeros convenios internacionales que incluyeron reglas aplicables a Ios CANI fueron los cuatro Convenios de Ginebra de 1949. Sin embargo, dichos tratados establecieron una regulación bastante escueta, que se limita a una única disposición: el artículo 3 común, que ha sido denominada por el Comité Internacional de la Cruz Roja (en adelante, "CICR") (2020) como una "convención en miniatura" (párr. 390). La regulación fue luego detallada en el Protocolo II Adicional a los Convenios de Ginebra, que estableció normas adicionales para los CANI. En lo que respecta a la costumbre internacional, el estudio del CICR sugiere que la mayoría de las normas de Derecho Consuetudinario son aplicables tanto a los CAI como a los CANI (Henckaerts \& DoswaldBeck, 2005)(15), aunque esa posición ha sido criticada por parte de la doctrina (Bellinger \& Haynes, 2007; Dinstein, 2014)(16).

Los CANI tienen esencialmente dos supuestos de aplicación, que están sujetos a exigencias y umbrales diversos. El primer umbral es el del artículo 3 común a los Convenios de Ginebra. Si bien dicha norma solo indica que el conflicto armado no debe ser de índole internacional y no precisa sus elementos, en el ya citado caso Tadić, el TPIY (1995) exigió la verificación de "violencia armada prolongada entre autoridades gubernamentales y grupos armados organizados o entre dichos grupos dentro de un Estado" (párr. 70)(17). Por lo anterior, se ha considerado que los CANI regulados por el artículo 3 común están sujetos a dos requisitos: una cierta intensidad de la violencia y un nivel mínimo de organización de los grupos involucrados (Sivakumaran, 2012; Akande, 2019; CICR, 2020).

La jurisprudencia ha entregado diversos criterios que asisten en la determinación de estos dos elementos. Por ejemplo, en lo que respecta a la intensidad, el TPIY en el caso Haradinaj (2008) indicó:

Por lo tanto, el criterio de la violencia armada prolongada ha sido interpretado en la práctica, incluso por la propia Sala de Primera Instancia de Tadić, en el sentido de que se refiere más

(12) La traducción es propia, original en inglés.

(13) Para mayor detalle de estas hipótesis y sus supuestos de aplicación véase Vité (2009), Akande (2019), y el comentario al artículo 2 común del CICR (2020).

(14) Según el trabajo del CICR, de 161 normas de Derecho Internacional Humanitario Consuetudinario identificadas, 159 de ellas aplican a los conflictos armados internacionales (Henckaerts \& Doswald-Beck, 2005).

(15) Según el estudio del CICR, de 161 normas de Derecho Internacional Humanitario Consuetudinario identificadas, 140 aplicarían a CANI (y 8 posiblemente también podrían aplicar a CANI).

(16) En este sentido, véase también el análisis contenido en Wilmshurst \& Breau (2007), que contiene varios trabajos que estudian críticamente el estudio del CICR, su metodología y comentan algunas de las normas identificadas por el Comité.

(17) La traducción es propia, original en inglés ("protracted armed violence between governmental authorities and organized armed groups or between such groups within a State"). 
a la intensidad de la violencia armada que a su duración. Las Salas de Primera Instancia se han basado en factores indicativos pertinentes para evaluar el criterio de "intensidad", ninguno de los cuales es, en sí mismo, esencial para establecer que se cumple el criterio. Estos factores indicativos incluyen el número, la duración y la intensidad de los enfrentamientos individuales; el tipo de armas y otros equipos militares utilizados; el número y el calibre de las municiones disparadas; el número de personas y el tipo de fuerzas que participan en los combates; el número de víctimas; el alcance de la destrucción material; y el número de civiles que huyen de las zonas de combate. La participación del Consejo de Seguridad de la ONU también puede ser un reflejo de la intensidad de un conflicto (párr. 49)(18)

El mismo TPIY, en el caso Boškoski \& Tarčulovski (2008) complementó este requisito de intensidad, al señalar:

Las Salas de Primera Instancia han tenido en cuenta varios factores indicativos para evaluar la "intensidad" del conflicto. Entre ellos, la gravedad de los ataques y si se ha producido un aumento de los enfrentamientos armados, la extensión de los enfrentamientos sobre el territorio y durante un período de tiempo, cualquier aumento del número de fuerzas gubernamentales y la movilización y distribución de armas entre ambas partes del conflicto, así como si el conflicto ha atraído la atención del Consejo de Seguridad de las Naciones Unidas y si se han aprobado resoluciones sobre el asunto. Las Salas de Primera Instancia también han tenido en cuenta a este respecto el número de civiles que se han visto obligados a huir de las zonas de combate; el tipo de armamento utilizado, en particular el uso de armas pesadas, y otros equipos militares, como tanques y otros vehículos pesados; el bloqueo o el asedio de las ciudades y el intenso bombardeo de las mismas; el alcance de la destrucción y el número de víctimas causadas por los bombardeos o los combates; la cantidad de tropas y unidades desplegadas; la existencia y el cambio de líneas de frente entre las partes; la ocupación de territorio, y de ciudades y pueblos; el despliegue de fuerzas gubernamentales en la zona de crisis; el cierre de carreteras; las órdenes y acuerdos de alto el fuego, y el intento de los representantes de las organizaciones internacionales de mediar y hacer cumplir los acuerdos de alto el fuego ${ }^{(19)}$ (párr. 177).

Luego, en lo que respecta al criterio de la organización, en el caso Haradinaj (2008), el TPIY hizo referencia a los siguientes elementos:

En cuanto a los grupos armados, las Salas de Primera Instancia se han basado en varios factores indicativos, ninguno de los cuales es, en sí mismo, esencial para establecer si se cumple el criterio de "organización". Estos factores indicativos incluyen la existencia de una estructura de mando y de normas y mecanismos disciplinarios dentro del grupo; la existencia de un cuartel general; el hecho de que el grupo controle un determinado territorio; la capacidad del grupo de acceder a armas, a otros equipos militares, a reclutas y a de planificar, coordinar y llevar a cabo operaciones militares, incluidos los movimientos de tropas y la logística; su capacidad para definir una estrategia militar unificada y utilizar tácticas militares; y su capacidad para hablar con una sola voz y negociar y concluir acuerdos como los acuerdos de alto el fuego o de paz (párr. 60) (20).

Por su parte, el segundo umbral de los CANI es el del Protocolo II Adicional a los Convenios de Ginebra. Este segundo supuesto de aplicación es considerablemente más exigente -según Akande (2019), tiene su origen en los criterios utilizados antiguamente para el reconocimiento de la beligerancia en guerras civiles-, y se encuentra previsto en el artículo 1(1), que dispone:

El presente Protocolo, que desarrolla y completa el artículo 3 común a los Convenios de Ginebra del 12 de agosto de 1949, sin modificar sus actuales condiciones de aplicación, se aplicará a todos los conflictos armados que no estén cubiertos por el artículo 1 del Protocolo adicional a los Convenios de Ginebra del 12 de agosto de 1949 relativo a la protección de las víctimas de los conflictos armados internacionales (Protocolo I) y que se desarrollen en el territorio de una Alta Parte contratante entre sus fuerzas armadas y fuerzas armadas disidentes o grupos armados organizados que, bajo la dirección de un mando responsable, ejerzan sobre una parte de dicho territorio un control tal que les permita realizar operaciones militares sostenidas y concertadas y aplicar el presente Protocolo.

Existen varias diferencias entre ambos umbrales. En primer lugar, el Protocolo II solo regula conflictos armados en que participen las fuerzas armadas, y no regula conflictos que tengan lugar solo entre diversos grupos armados organizados, que sí se encuentran cubiertos por el artículo 3 común a los Convenios de Ginebra. Asimismo, el Protocolo II incorpora como requisitos algunos elementos que habían sido identificados por la jurisprudencia como meros factores indicativos de los criterios de intensidad u organización. De esta manera, la existencia de un mando responsable, el control sobre el territorio, la capacidad de realizar operaciones militares sostenidas y concertadas, entre otros ${ }^{(21)}$, pasan a ser

(18) Traducción propia, original en inglés.

(19) Traducción propia, original en inglés.

(20) Traducción propia, original en inglés.

(21) Para más detalles de las diferencias entre los umbrales del artículo 3 común y el Protocolo Il véase Akande (2019). 
requisitos esenciales para la verificación del umbral, sin los cuales la normativa del Protocolo II Adicional no opera. De esta manera, el Protocolo II solo cubre un grupo pequeño de conflictos armados no internacionales de alta intensidad, mientras que la mayoría de los conflictos armados no internacionales quedan regidos por el artículo 3 común (La Haye, 2008).

Un aspecto común, sin embargo, es que ninguno de los dos regímenes jurídicos aplica a situaciones de tensiones o disturbios internos. De hecho, el artículo 1(2) del Protocolo Il Adicional lo señala expresamente, excluyendo casos de tensiones y disturbios interiores, "tales como los motines, los actos esporádicos y aislados de violencia y otros actos análogos, que no son conflictos armados". Si bien esa regla no aparece expresamente en los Convenios de Ginebra, el CICR (2020) ha indicado que la misma "también se considera correcta para el articulo 3 común” (párr. 420). De esta manera, hechos de violencia que no cumplan el umbral del artículo 3 común o del Protocolo II no se encontrarán regulados por el Derecho Internacional Humanitario. Ahora bien, como ha señalado el CICR (1987), esto no significa que no exista una protección jurídica internacional aplicable a estas situaciones, ya que están contempladas en los instrumentos universales y regionales de derechos humanos (párr. 4479) ${ }^{(22)}$.

\section{La situación chilena entre 1973 y 1990: ¿Un conflicto armado no internacional?}

Una vez establecido el marco general del Derecho Internacional Humanitario, y aclarada la necesidad de que exista un conflicto armado como presupuesto fáctico de aplicación de dicho régimen jurídico, cabe examinar brevemente la situación chilena a fin de determinar -al menos preliminarmente- si se cumplían dichos elementos de hecho.

Dicho análisis, sin embargo, no requiere tratar a la dictadura militar chilena como una unidad, abarcando toda su extensión temporal (11 de setiembre de 1973 a 11 de marzo de 1990). Para que el Derecho Internacional Humanitario opere, no es necesario acreditar que existió un conflicto armado por diecisiete años, y es posible que el periodo relevante sea más acotado. Sin embargo, las normas internacionales en esta materia solo serán aplicables a los hechos que hayan tenido lugar dentro del espacio temporal de un conflicto armado.
No obstante la clara relevancia de esta materia, ni la doctrina ni la jurisprudencia chilena han examinado mayormente si los hechos que tuvieron lugar en Chile cumplen con el umbral del artículo 3 común, que constituía norma vigente en Chile al momento de iniciarse la dictadura militar ${ }^{(23)}$. Como se verá en la sección siguiente, la mayor parte del análisis se ha enfocado en los efectos jurídicos del Decreto Ley 5, y no en la verificación de los elementos fácticos de un conflicto armado. Los criterios recién examinados relativos a la intensidad del conflicto y el carácter organizado de los grupos han estado prácticamente ausentes de la discusión jurídica chilena.

Existen, sin embargo, unas pocas excepciones. Entre ellos, se encuentra José Zalaquett (2007), quien sostenía:

En cuanto a las condiciones materiales para la aplicación del Derecho Internacional Humanitario, esto es la existencia de un conflicto armado, se puede decir lo siguiente: (i) es razonable concluir que en Chile hubo un conflicto armado interno de los mencionados en el Artículo 3 Común de los Convenios de Ginebra de 1949 el mismo día 11 de setiembre, fecha del golpe militar que derrocó al gobierno del Presidente Allende, y en los días inmediatamente posteriores, hasta que las fuerzas golpistas sofocaron toda resistencia armada; (ii) es razonable, igualmente, concluir que semejante tipo de conflicto armado existió nuevamente en Chile a partir de 1979 y por varios años, luego de que ciertos sectores de oposición al gobierno militar, en particular el Partido Comunista y el Partido de Izquierda Revolucionaria (MIR) iniciaron acciones organizadas de lucha armada (p. 192).

Siguiendo a Zalaquett, pueden identificarse dos periodos relevantes para el análisis. El primero corresponde al periodo entre el 11 de setiembre de 1973 y los días inmediatamente posteriores, mientras que el segundo abarca el periodo desde 1979 en adelante. A continuación, se esbozan brevemente algunos de los hallazgos de la

(22) Véase, en el mismo sentido, Comité Internacional de la Cruz Roja (2014).

(23) En efecto, los 4 Convenios de Ginebra fueron ratificados por Chile el 12 de octubre de 1950. En cambio, el Protocolo II Adicional fue ratificado en democracia, el 24 de abril de 1991. 
historia sobre este periodo, que pueden ser relevantes para determinar la existencia de un conflicto armado.

\subsection{El golpe de Estado y los días posteriores}

El día 11 de setiembre de 1973, el almirante José Toribio Merino, el General de la Fuerza Aérea Gustavo Leigh, el General de Carabineros César Mendoza y el General del Ejército Augusto Pinochet ejecutaron el golpe de Estado contra el Presidente Salvador Allende, que llevaba unos meses siendo planificado.

Contrario a su visibilidad posterior, Augusto Pinochet no fue el arquitecto del golpe. Existe bastante acuerdo entre quienes se dedican a la historia de que Pinochet se habría sumado en las etapas finales de la planificación. Sin embargo, como destacan Correa et al. (2001), los militares consideraban que su presencia era relevante "pues de lo contrario arriesgaban el peligro de un posible quiebre entre las fuerzas militares, el que inevitablemente conduciría a una guerra civil" (p. 274).

En efecto, la participación de Pinochet parece haber sido suficiente para evitar dicha guerra. Como destaca Pinto Vallejos (2006), si bien previo al 11 de setiembre existía una planificación de los Partidos Comunista y Socialista para organizar una resistencia militar en las poblaciones en el evento de un golpe, dicha estrategia asumía que existiría un porcentaje relevante de militares que se mantendrían fieles al gobierno constitucional. Sin embargo, "[c]omo ello no ocurrió, la resistencia comunista prácticamente no pasó de la etapa de planificación" (p. 166). En el mismo sentido, Politzer (2013) recoge el testimonio de Carlos Altamirano -Secretario General del Partido Socialista para el golpe de Estado-, quien desmiente categóricamente la existencia de una coordinación o voluntad para preparar una defensa armada del gobierno de Allende: "[l]o concreto es que nuestros operativos militares eran mínimos, que no estaban coordinados con los otros partidos de la Unidad Popular y que los dispositivos programados para un eventual golpe no operaron el 11 de setiembre". En concreto, Altamirano indica que el día del golpe militar, "[h]ubo cierta resistencia en algunas fábricas, pero la verdad es que fue mínima, no había ninguna posibilidad de enfrentarse a los militares".

Otro actor relevante fue el Movimiento de Izquierda Revolucionaria ("MIR"). Al respecto, Pinto Vallejos (2006) indica que el 11 de setiembre, el MIR participó en algunos combates en Santiago y Panguipulli, pero "no estuvo totalmente a la altura de lo que se podría haber esperado de un partido que venía insistiendo desde sus orígenes en la centralidad de la faceta militar para los procesos revolucionarios" (pp. 167-168). En esa misma línea, uno de sus antiguos militantes indicó con posterioridad que los planes militares del MIR eran "divagaciones de gente que sabía muy poco o nada realmente del problema militar, de organización de fuerzas, de los recursos materiales para esa fuerza, cuestiones en el aire que no respondían a una disposición real de fuerzas o de recursos, lo que quedó demostrado en los hechos" (Pinto
Vallejos, 2006, p. 168) mientras que otro señaló "[q]uedó al descubierto que el poder popular no era más que una idea en nuestras cabezas y no una realidad que pudiera organizar la resistencia y ni siquiera proteger a la militancia revolucionaria" (Pinto Vallejos, 2006, p. 169).

En la misma línea, Correa et al. (2001) sostienen que la resistencia que esperaban los golpistas fue sorprendentemente débil: "[s]alvo algunos francotiradores apostados en los edificios contiguos a La Moneda y la acción de los integrantes del GAP [Grupo de Amigos Personales], quienes se enfrentaron con las fuerzas sublevadas, la resistencia fue casi nula, contrastando con la feroz y violenta ofensiva de los atacantes" (p. 275). Más adelante, Correa et al. (2001) reiteran "el régimen tomó posesión total del país en un lapso brevísimo, no hubo resistencia armada significativa que vulnerara el orden recién impuesto" (p. 280), y califican este periodo, no como un estado de guerra, sino un "estado de terror" (Correa et al., 2001, p. 281).

Es difícil que esta débil resistencia pueda cumplir con los supuestos del artículo 3 común a los Convenios de Ginebra. Por una parte, los enfrentamientos tuvieron una muy baja intensidad. En efecto, no solo duraron apenas unos días -el mismo Zalaquett (2007) reconocía que ya no existían enfrentamientos relevantes el 22 de setiembre de 1973-, sino que no parece cumplir con ninguno de los factores indicativos que fueron previamente reseñados. Los antecedentes históricos dan cuenta de la participación de muy pocos individuos, que portaban armas de bajo calibre.

Al respecto, Correa et al. (2001) hacen referencia al uso de "revólveres, fusiles, ametralladoras y pistolas" (p. 269). Por su parte, Pinto Vallejos (2006) indica que la resistencia del MIR se vio coartada por "la falta de recursos militares para hacer efectivo el plan de resistencia al golpe" (p. 169). En la misma línea, González (2012) recoge el relato de un dirigente estudiantil socialista que intentó armar un foco de resistencia, quien dio cuenta de la inexistencia de un aparato militar: "todo el alarde de armas era una estupidez [...] [l]o que encontramos era 
La aplicación de los Convenios de Ginebra en ausencia de un conflicto armado: El caso de la dictadura militar chilena

The application of the Geneva Conventions in the absence of an armed conflict: The case of the Chilean military dictatorship

absolutamente ridículo: 8 a 10 armas personales, propias de un grupo escolta, pero no de un grupo paramilitar" (p. 386). En suma, las armas utilizadas y las municiones involucradas no parecen cumplir con los niveles de intensidad antes reseñados, y que hacen referencia a municiones de alto calibre, existencia de armas pesadas, tanques, y algunos métodos y medios de combate particulares como bombardeos, despliegue de tropas y unidades, entre otros.

Adicionalmente, y como fue reseñado supra, el elemento de intensidad también se ha examinado en relación con la cantidad de víctimas resultantes del conflicto. En el caso chileno, los números parecen dar cuenta de una masacre de la población civil, y no son concordantes con un real enfrentamiento. En ese sentido, y si bien reconocen una falta de precisión en los números, Correa et al. (2001) indican que habrían existido 1,500 personas caídas en enfrentamientos contra los militares, sumados a personas muertas y/o desaparecidas tras la detención entre 1973 y 1974. Ello se contrasta con apenas 30 bajas militares en el mismo periodo.

El segundo criterio relevante para la existencia de un conflicto armado no internacional es la organización de los grupos. Sin embargo, este requisito tampoco parece configurarse. Así, uno de los grupos de resistencia a los que hace referencia la historia es el GAP o "Grupo de Amigos Personales", que está muy lejos de cumplir con el elemento de la organización: correspondía simplemente a un grupo de jóvenes del MIR y de las Juventudes Socialistas que acompañaban al Presidente Allende (Correa et al., 2001). Los mismos no contaban con una estructura de mando, mecanismos disciplinarios, acceso a equipos militares, ni mucho menos controlaban territorio ni desarrollaban una estrategia militar unificada. Por su parte, en lo que respecta al MIR, sus propios militantes reconocían que dicho grupo no contaba con una organización adecuada para poder organizar la resistencia o siquiera proteger a su propia militancia (Pinto Vallejos, 2006).

De esta manera, la situación chilena parece asemejarse más a una situación de disturbios o tensiones internas. En ese sentido, resulta ilustrativo considerar la definición de disturbios internos entregada por el CICR (1971), que sostiene:

Se trata de situaciones en las que no hay un conflicto armado no internacional como tal, pero existe un enfrentamiento dentro del país, que se caracteriza por una cierta gravedad o duración y que implica actos de violencia. Estos últimos pueden asumir diversas formas, desde la generación espontánea de actos de revuelta hasta la lucha entre grupos más o menos organizados y las autoridades en el poder. En estas situaciones, que no necesariamente degeneran en una lucha abierta, las autoridades en el poder recurren a amplias fuerzas policiales, o incluso a fuerzas armadas, para restablecer el orden interno (p. 79, traducción propia).

Por su parte, sobre las tensiones internas, el Comité (1978) ha considerado los siguientes elementos: a) Situaciones de grave tensión, de carácter político, religioso, racial, social, económico, etc;

b) Una secuela de un conflicto armado o de disturbios internos.

En tales situaciones se dan una o varias de las siguientes características, o incluso todas ellas

1. Detenciones a gran escala;

2. Un gran número de detenidos políticos

3. Probables malos tratos o condiciones inhumanas de detención

4. Suspensión de las garantías legales fundamentales como resultado de la promulgación de la ley de emergencia, o de las circunstancias;

5. Presuntas desapariciones de personas ( $p$. 211, traducción propia).

Los hechos ocurridos el 11 de setiembre de 1973 y los días inmediatamente posteriores se enmarcan más claramente en este escenario que en el de un conflicto armado no internacional. En consecuencia, las normas de Derecho Internacional Humanitario no serían aplicables a los hechos ocurridos en este periodo.

\subsection{El periodo entre 1973-1979}

Los relatos sobre hechos de resistencia en los años que siguieron al golpe de Estado son escasos, y no parecen acercarse al umbral exigido para determinar la existencia de un conflicto armado no internacional. Eso explica por qué ni siquiera Zalaquett (2007) consideró este periodo como uno de potencial aplicación de los Convenios de Ginebra.

Al respecto, Pinto Vallejos (2006) relata algunos ejercicios de resistencia del MIR durante los años 70 , pero indica que éstos fueron de carácter muy limitado. El grupo había sufrido importantes bajas entre su militancia, incluyendo algunos de sus dirigentes más emblemáticos como Bautista van Shouwen y Miguel Enríquez y figuras clave como el jefe del aparato militar del MIR, José Bordaz. Asimismo, otros líderes como Andrés Pascal Allende y Nelson Gutiérrez debieron huir al exilio. 
Fue recién en 1978 que el MIR adoptó un plan que buscaba avanzar en una línea militar, y que se posibilitó por la llegada de militantes que habían participado en las luchas revolucionarias en América Central. Sin embargo, incluso en este periodo, la intensidad de los hechos parece insuficiente para cumplir el umbral de los CANI. Así, además de algunas operaciones de carácter más simbólico, Pinto Vallejos (2006) describe acciones como "bombazos, atentados contra el tendido eléctrico, levantamiento de barricadas, asaltos a bancos [...] y tiroteos a cuarteles policiales y de la CNI" (p. 190). Nuevamente, estos hechos se acercan más al escenario de los disturbios internos que a un conflicto armado. A mayor abundamiento, autores como Cavallo, Salazar y Sepúlveda (1997) cuestionan que todos los hechos que se atribuyen al MIR en este periodo hayan sido realmente de su autoría, lo que pone en duda la relevancia de estos hechos para el cumplimiento del umbral de los conflictos armados: "la mayoría de los ataques no eran efectuados por grupos de izquierda, sino por miembros de la DINA [la Dirección de Inteligencia Nacional]" (p. 248).

Si la resistencia que tuvo lugar tras el 11 de setiembre de 1973 no cumple con los requisitos del artículo 3 común, mucho menos lo hacen estas actividades insurgencia que se enmarcan casi a la perfección con la figura de los disturbios internos, bajo la cual -como ya se reseñaba supra-, el Derecho Internacional Humanitario no es aplicable. Lo anterior se confirma por la evaluación realizada por el propio Comité Internacional de la Cruz Roja respecto de la situación chilena. Así, en un informe que se refiere precisamente a su trabajo en situaciones no cubiertas por el Derecho Internacional Humanitario, el CICR (1978) hace referencia a las visitas que ha realizado a personas detenidas en situaciones de disturbios o tensiones internas. Dentro de las visitas realizadas bajo esta categoría, que está excluida de los Convenios de Ginebra, menciona precisamente las visitas a Chile(24).

\subsection{Los movimientos de resistencia a partir de 1979}

Las actividades realizadas por los grupos de oposición durante la década de los ochenta presentan una nueva oportunidad para examinar el cumplimiento del umbral de los CANI. De hecho, como ya se adelantó, Zalaquett (2007) sostenía que desde 1979, el actuar del Partido Comunista y del MIR podía considerarse un acto organizado de lucha armada suficiente para hacer aplicable el Derecho Internacional Humanitario.

Sin embargo, algunos relatos históricos dan cuenta de hechos de resistencia de baja o mediana intensidad. Por ejemplo, Politzer (1988) recoge el testimonio de un joven poblador perteneciente a las Juventudes Comunistas, quien hacía referencia al desequilibrio en los enfrentamientos: "[s]on peleas harto desequilibradas, apenas se logra retenerlos un poco en base a piedras, unas molotov o lo que se tenga a mano" (p. 44). El joven indica más adelante que "el único trabajo militar que hice en la Jota ${ }^{(25)}$ fue poner cargas en postes con transformadores, que era lo que se hacía a fines del 83 y principios del 84" (p. 46).

Es cierto, sin embargo, que hubo algunos intentos de resistencia de mayor envergadura. En ese sentido, Pinto Vallejos (2006) hace referencia a las tentativas del MIR de establecer una guerrilla permanente para enfrentarse a la dictadura. Sin embargo, aunque existieron una serie de preparativos en Neltume, no se alcanzaron a realizar operaciones propiamente militares, y el grupo terminó siendo descubierto y aplastado por la dictadura, resultando en la muerte sus integrantes (Pinto Vallejos, 2006; Valdivia Ortiz de Zárate, 2006). Un intento similar tuvo lugar en Nahuelbuta. Sin embargo, los guerrilleros se dedicaron a recorrer el terreno sin realizar operaciones militares, y luego se replegaron tras tomar conocimiento del destino de sus camaradas de Neltume (Pinto Vallejos, 2006). Otros actos del MIR durante los ochenta incluyeron ataques y asaltos a bancos, comisarías de Carabineros, cuarteles de la Policía de Investigaciones, además de ataques y atentados contra ciertos oficiales y suboficiales de las FF.AA y/o Carabineros (Cavallo, Salazar \& Sepúlveda, 1997 y Pinto Vallejos \& Leiva Flores, 2008). Estos hechos, aunque violentos, siguen acercándose más a los disturbios internos. En ese sentido, Pinto Vallejos y Leiva Flores (2008) son categóricos: "[s]i bien se logró alguna efectividad y visibilidad en el plano de la propaganda armada, se estuvo muy lejos de alcanzar los niveles mínimos de contundencia como para constituir una amenaza real para el aparato militar en que se sustentaba, en última instancia, la proyección del régimen" (p. 107).

En lo que respecta al Partido Comunista, Álvarez Vallejos (2008) reconoce que el mismo siguió un camino de radicalización, asumiendo formas de lucha armada, aunque indica que ella habría sido "cosa de minorías,

(24) Véase, en el mismo sentido, Comité Internacional de la Cruz Roja (2014).

(25) La "Jota" es el nombre que se le da coloquialmente en Chile a las Juventudes Comunistas. 
La aplicación de los Convenios de Ginebra en ausencia de un conflicto armado: El caso de la dictadura militar chilena

The application of the Geneva Conventions in the absence of an armed conflict: The case of the Chilean military dictatorship

ajenas al resto de la población" (p. 20). En este ámbito, se hace referencia a la creación del Frente Patriótico Manuel Rodríguez ("FPMR"), que tenía por propósito servir como una fuerza militar que fuera aún más amplia que los comunistas, de manera de cuidar a los cuadros legales y lograr una convocatoria mayor. Si bien el FPMR es frecuentemente descrito como un grupo armado, las acciones realizadas siguen sin alcanzar una gran envergadura: apagones, secuestros, actos contra cuarteles de Carabineros, bancos, empresas norteamericanas, acciones contra vías férreas, construcción de barricadas, entre otros actos de violencia. En ese sentido, es llamativo que Álvarez Vallejos (2008) considere que el acto de "mayor envergadura" de 1985 fue la realización de "sabotajes a torres de alta tensión" (p. 56), que dejaron sin luz a la zona central del país. Por otra parte, Politzer (1988) también hace referencia a operaciones con coches bomba, robos de vehículos, tomas de medios de prensa, quema de locales, ataques a bancos, entre otras operaciones.

El análisis de este periodo se dificulta cuando se considera que mucha de la información sobre supuestos "enfrentamientos" entre la dictadura y los grupos de resistencia, en realidad correspondía a hechos falsos o montajes difundidos por el propio régimen militar para ocultar los asesinatos extrajudiciales de opositores. Entre varios otros ejemplos, puede hacerse referencia a la matanza de Corpus Christi en la llamada Operación Albania de 1987, por medio de la cual la dictadura asesinó a 12 miembros del FPMR (Correa et al., 2001; Skoknic, s. f). La operación fue falsamente informada por la prensa como un "enfrentamiento a tiros con efectivos de seguridad" (La Tercera, 1987), "un enfrentamiento [...] el sujeto, en un momento determinado [...] se dio media vuelta y comenzó a disparar contra la patrulla policial" (La Cuarta, 1987) y "enfrentamiento a bala con las fuerzas de seguridad" (El Mercurio, 1987).

Los hechos de violencia más graves, y que resultan mejores candidatos para la identificación de los elementos propios de un conflicto armado no internacional, tuvieron lugar en 1986. En primer lugar, el FPMR intentó internar un masivo arsenal en Carrizal Bajo, al norte de Chile. Así, como relatan Cavallo, Salazar \& Sepúlveda (1997), el FPMR se organizó para recibir más de 50 toneladas en materiales bélicos por el mar que incluían fusiles M-16, lanzacohetes RPG-7 y LOW, granadas de mano, ametralladoras pesadas, toneladas de explosivos de variados poderes, bombas, detonantes, además de millones de cartuchos de diversos calibres. Sin embargo, casi todo el arsenal fue detectado prontamente por la Central Nacional de Inteligencia ("CNI"). De las armas restantes, algunas fueron destinadas al intento fallido de magnicidio contra Augusto Pinochet que tendría lugar unas semanas después en la zona del Cajón del Maipo, y que resultó en la muerte de cinco escoltas, mientras que otros doce quedaron con heridas graves. Ella fue calificada por Álvarez Vallejos (2006) como "la acción militar de mayor envergadura en la historia de los movimientos armados en Chile" (p. 70).

La gran mayoría de los hechos descritos, si bien violentos, parecen ser aún insuficientes para cumplir con el umbral del artículo 3 común. Es cierto que la creación del Frente Patriótico Manuel Rodríguez supuso la incorporación de un grupo con mayores niveles de organización. De hecho, el juramento de sus integrantes incluía un compromiso a la disciplina, hacía referencia al grado militar, y establecía una obediencia jerárquica frente a la dirección nacional (Álvarez Vallejos, 2008). Sin embargo, el elemento de la intensidad sigue sin verificarse con claridad. No hay duda que el acceso a armas importadas desde Carrizal y el intento de magnicidio de Pinochet son hechos de mayor envergadura, pero no es claro que sean suficientes para poder calificar el contexto como uno de un conflicto armado.

En suma, los antecedentes fácticos no parecen ser especialmente propicios para la alegación de que, durante la dictadura militar chilena, se desarrolló un conflicto armado no internacional. Salvo algunos periodos específicos que podrán requerir un análisis mayor (sobre todo el periodo de 1986), la inmensa mayoría de los hechos de violencia que han sido recopilados por quienes se dedican a la historia parecen ser insuficientes para cumplir con los requisitos que hacen aplicable el artículo 3 común de los Convenios de Ginebra. Ahora bien, el análisis aquí realizado corresponde a un estudio general de los antecedentes históricos, pero no pretende reemplazar un escrutinio más exhaustivo sobre los movimientos de resistencia en Chile, que corresponde realizar a quienes se especializan en la historia de Chile. Por ello, la conclusión aquí alcanzada es necesariamente preliminar, y está sujeta a una revisión y complementación considerando otros antecedentes relevantes sobre el periodo dictatorial. Sin embargo, el estudio hasta aquí realizado es suficiente para cuestionar -al menos en principio- el relato sobre la "guerra civil", que fue muchas veces sostenido por la propia dictadura, o al menos poner en duda su extensión temporal.

Este análisis también sirve como antecedente y contraste al estudio de la 
jurisprudencia chilena que se realiza en la sección siguiente. Como se verá, la Corte Suprema chilena parece haber preferido usar el atajo del Decreto Ley 5 e ignorar casi por completo los antecedentes fácticos sobre la resistencia a la dictadura, que resultaban fundamentales para determinar la aplicación de los Convenios de Ginebra a los hechos.

\section{Una aproximación poco ortodoxa al Derecho Internacional Humanitario: La jurisprudencia de la Corte Suprema chilena}

Una vez reinstaurada la democracia en Chile, a partir del 11 de marzo de 1990, las víctimas de violencia estatal comenzaron a presentar una serie de acciones judiciales en sede civil y penal, muchas de las cuales se basaron en los Convenios de Ginebra de 1949. Sin embargo, durante la década de los noventa, la jurisprudencia de la Corte Suprema fue bastante consistente en señalar que no se cumplían los supuestos de aplicación del Derecho Internacional Humanitario, al no haber existido en Chile un conflicto armado no internacional. Por ejemplo, en el año 1996, la Corte Suprema indicó que "no se puede estimar fundadamente que a la época de la comisión del delito existiera efectivamente en el territorio nacional un conflicto bélico entre fuerzas contendientes de aquéllas a las que aluden los Convenios de Ginebra" (Corte Suprema, Rol 263-96, considerando 7).

Dicha jurisprudencia, sin embargo, comenzó a variar durante la década de los 2000. Contrario a lo que pudiera esperarse, dicho cambio no se debió a un análisis detallado sobre los supuestos de aplicación del Derecho Internacional Humanitario, sino que se basó casi exclusivamente en el Decreto Ley 5, promulgado por el régimen militar dentro de los primeros días de la dictadura, y que señalaba que Chile se encontraba en "estado o tiempo de guerra".

\subsection{La relevancia del Decreto Ley ¿Un conflicto armado en Chile?}

Según ya fue adelantado, el 12 de setiembre de 1973, la dictadura militar adoptó el Decreto Ley 5, por medio del cual declaró que el Estado de Sitio decretado por conmoción interna -previamente establecido por medio de Decreto Ley 3 del 11 de setiembre de 1973-, debía entenderse como un "estado o tiempo de guerra", que hacía aplicable el Código de Justicia Militar y reconocía la jurisdicción de los tribunales militares para conocer de ciertos delitos.

Ahora bien, las primeras decisiones de la Corte Suprema tras el retorno de la democracia señalaron que el Decreto Ley 5 solo tenía el efecto de aplicar la legislación del tiempo de guerra, y que el mismo constituía una ficción sin correlato en los hechos ${ }^{(26)}$. Por ejemplo, en el año 1996, la Corte Suprema indicó que el Decreto Ley 6 solo se había dictado para el efecto de aplicar la legislación en tiempo de guerra, "sin que en realidad concurran los presupuestos de un conflicto bélico como al que se hace mención en los Convenios de Ginebra" (Corte Suprema, Rol 263-96, considerando 7). Casi diez años después, la Corte Suprema mantenía el mismo criterio. Así, en una sentencia del año 2005, y conociendo de un caso relativo al crimen de secuestro calificado perpetrado el día 5 de octubre de 1973, la Corte Suprema revocó la sentencia de la Corte de Apelaciones de Temuco -que había sostenido la aplicabilidad de los Convenios de Ginebra sobre la base del Decreto Ley 5, indicando:

No se ha acreditado ni tenido por establecido en autos que en la fecha señalada existía en Chile una oposición entre dos fuerzas armadas o bien entre las fuerzas armadas de Chile y uno o más grupos armados que no reconocían la autoridad de la primera y que estaban bajo el mando de una autoridad responsable, que ejercía dominio o control sobre una parte del territorio chileno, lo que le permitía realizar operaciones militares sostenidas y concertadas y aplicar las disposiciones de Derecho Humanitario (Corte Suprema, Rol 457-2005, considerando 7).

De esta manera, la mayoría de la Corte Suprema(27) indicó que el Decreto Ley 5 no era suficiente para acreditar la existencia de dichos elementos fácticos, haciendo en consecuencia inaplicables los Convenios de Ginebra. Resulta peculiar, sin embargo, que el umbral requerido por la Corte Suprema tenía una clara inspiración en el Protocolo Adicional II a los Convenios de Ginebra -que no se encontraba vigente en Chile durante la dictadura militar-, y que la Corte no reconociera el ya referido umbral aplicable al artículo 3 común a los Convenios de Ginebra, que se encontraba en proceso de desarrollo por parte del Tribunal Penal Internacional para la ex Yugoslavia de manera contemporánea.

(26) Una revisión de la jurisprudencia de los tribunales superiores de justicia en esta materia, desde 1990 en adelante, véase en Irigoin Barrena \& Espaliat Larson (2003); Díaz Tolosa (2006); y Galdámez Zelada (2012).

(27) Ministro Nibaldo Segura y abogados integrantes José Fernández y Luz María Jordán. 
La aplicación de los Convenios de Ginebra en ausencia de un conflicto armado: El caso de la dictadura militar chilena

The application of the Geneva Conventions in the absence of an armed conflict: The case of the Chilean military dictatorship

Esa decisión, sin embargo, estuvo acompañada de un voto disidente de los Ministros Enrique Cury y Jaime Rodríguez, quienes indicaron que el Decreto Ley 5 suponía que el territorio nacional se encontraba jurídicamente en estado de guerra interna, aún a pesar de no cumplirse los requisitos de orden fáctico. Los mismos además sostuvieron que:

No es admisible que los mismos que se asilaron en las ventajas que les concedía la referida declaración de estado de guerra, establecido por el único instrumento legislativo disponible luego de haberse producido el quebrantamiento de la institucionalidad constitucional vigente hasta entonces, pretendan ahora desconocer su valor para ignorar las sanciones que al quebrantamiento de las leyes de tal estado y las limitaciones que a la autoexoneración respecto de ellas imponen los Convenios de Ginebra y los otros instrumentos internacionales ya entonces en vigor sobre la materia. Si valiéndose de la superioridad de la fuerza se consagró un estado de guerra para facilitar la lucha contra los que se oponían al gobierno de facto, hay que estarse también a las consecuencias que se siguen de haber quebrantado la normativa que regula los conflictos bélicos en relación con el tratamiento de los combatientes, a los que ya no se podía considerar como delincuentes comunes y, mucho menos, hacer víctima de represiones brutales como aquella de que dan cuenta los antecedentes de este proceso. Una de las mencionadas consecuencias es, precisamente, la prohibición de autoexoneración por los crímenes de guerra que se hubieren cometido en esas circunstancias, contemplada expresamente en los Convenios de Ginebra (Corte Suprema, Rol 457-2005, Voto Disidente de los Ministros Cury y Rodríguez, párr. 3).

Al año siguiente, la posición de los Ministros Cury y Rodríguez se transformó en la posición de la mayoría de los ministros de la Corte Suprema. De esta manera, en una decisión de diciembre del año 2006, al conocer el caso del homicidio de los miembros del Movimiento de Izquierda Revolucionaria (MIR) en Choshuenco -que tuvo lugar el 23 de setiembre de 1973-, la Corte Suprema ${ }^{(28)}$ sostuvo que el Decreto Ley 5 hacía aplicable los Convenios de Ginebra y en general el Derecho Internacional Humanitario (Corte Suprema, Rol 559-2004). Ello fue criticado por el voto de minoría del Ministro Ballesteros, que indicó que la adopción del Decreto Ley no era suficiente para establecer la existencia de un conflicto armado no internacional, al no haber existido "una oposición entre dos fuerzas armadas o bien entre las fuerzas armadas de Chile y uno o más grupos armados que desconocían la autoridad de la primera y que estaban bajo el mando de una autoridad responsable, que ejercía dominio o control sobre una parte del territorio chileno, lo que le permitía realizar operaciones militares sostenidas y concertadas y aplicar las disposiciones de Derecho Humanitario" (Corte
Suprema, Rol 559-2004, Voto Disidente del Ministro Ballesteros, párr. 9), reiterando el umbral del Protocolo Adicional II, ya reseñado.

El año siguiente, la Corte Suprema volvió a recoger este criterio, indicando:

El examen de la normativa dictada luego del 11 de setiembre de 1973, así como el contexto en que se desarrollaron los hechos posteriores a esa data, permiten concluir que en la época en que ocurrieron los sucesos que dieron origen a la presente investigación, el territorio nacional se encontraba en la realidad y jurídicamente en estado de guerra interna. Razón suficiente para tener por establecido que en Chile existía un "conflicto armado no internacional", en los términos del artículo 3 común para los Convenios de Ginebra (Corte Suprema, Rol 6188-2006, considerando 21).

Sorprendentemente, dicha decisión fue redactada por el Ministro Ballesteros, el mismo autor del voto disidente antes mencionado y que sostenía una visión absolutamente opuesta sobre la aplicación de los Convenios de Ginebra.

Un poco más de un mes luego de dictada esa sentencia, la divergencia en la jurisprudencia de la Corte Suprema llegó a su mayor expresión, cuando el 27 de diciembre de 2007 la Corte Suprema dicta dos decisiones contradictorias. En la primera de dichas decisiones, una integración de la Corte Suprema ${ }^{(29)}$ volvió al criterio del año 1996 y 2005, señalando que no se verificaría el umbral necesario para la existencia de un conflicto armado no internacional (Corte Suprema, Causa Rol 3925-2005). En cambio, en la otra decisión de la misma fecha, una distinta integración de la Corte Suprema ${ }^{(30)}$ sostuvo que la normativa dictada luego del 11 de setiembre de 1973 permite dar por establecida la existencia de un conflicto armado no internacional en Chile (Corte Suprema, Causa Rol 1489-2007).

La falta de precisión continuó durante el año 2008. Así, en una decisión del mes

(28) Voto de mayoría: Ministros Alberto Chaigneau, Julio Torres y abogados integrantes Óscar Herrera y Domingo Hernández. Voto de minoría: Ministro Rubén Ballesteros.

(29) Integrada por los Ministros Nibaldo Segura, Rubén Ballesteros, Hugo Dolmestch, Patricio Valdés y Héctor Carreño.

(30) Integrada por los Ministros Alberto Chaigneau, Nibaldo Segura, Jaime Rodríguez, Rubén Ballesteros y Hugo Dolmestch. 
de mayo, la mayoría de la Corte Suprema ${ }^{(31)}$ indicó que no se verificaba el umbral de los conflictos armados no internacionales, y sostuvo:

La situación vivida en Chile a partir del día 11 de setiembre de 1973 , no es posible entenderla ni considerarla como un "conflicto armado sin carácter de internacional", ya que los grupos a los que se enfrentaron las Fuerzas Armadas no eran una fuerza militar organizada; no tenían una autoridad responsable de sus actos; no actuaron sobre un territorio determinado del Estado de Chile, así como nunca dispusieron de una parte del territorio nacional, ni de la población; nunca se les reconoció la condición de beligerantes; tampoco tenían un régimen con las características de un Estado; nunca nadie reconoció que estaban dispuestos a conformarse a las leyes y las costumbres de la guerra ni las autoridades civiles de los insurrectos -que por cierto no existían-, reconocieron que estaban obligadas por las disposiciones del Convenio. En la realidad los acontecimientos ocurridos a partir de 1973 no cumplían ninguna de las condiciones enumeradas" (Corte Suprema, Rol 3872-2007, considerando 7).

Por ello, la Corte concluyó:

EI D. L. 5 es claramente insuficiente para acreditar la existencia de los presupuestos fácticos señalados en las motivaciones precedentes $\mathrm{y}$, dado que ellos no se tuvieron por establecidos de otro modo, no es posible sostener que en Chile existía un "conflicto armado no internacional" el 21 de setiembre de 1973, razón por la que debe concluirse que no constituye un yerro dejar de aplicar los Convenios de Ginebra de 1949 en esta [sic] proceso (Corte Suprema, Rol 3872-2007, considerando 10).

Sin embargo, esta parece ser una de las últimas decisiones en que la Corte Suprema sostuvo la no aplicabilidad de los Convenios de Ginebra. Así, durante los años 2007, 2008 y 2009, la jurisprudencia sobre la aplicación del Derecho Internacional Humanitario fue asentándose, aunque existió una gran diversidad de elementos y criterios considerados por la Corte Suprema para determinar la aplicabilidad de los Convenios de Ginebra de 1949. Por ejemplo, en varias oportunidades, la Corte sostuvo que el Decreto Ley 5 suponía un "reconocimiento legislativo" del estado de guerra, realizado por el propio gobierno de facto ${ }^{(32)}$. En otra oportunidad, la Corte sostuvo que "el Golpe de Estado fue un acto de guerra" (Corte Suprema, Rol 4691-2007, considerando 12). En otros casos, la Corte Suprema ha señalado sencillamente que "el territorio nacional se encontraba en estado de guerra interna, realidad que es suficiente para concluir que en Chile existía un "conflicto armado no internacional" en los términos del artículo 3 común para los Convenios de Ginebra" (Corte Suprema, Rol 33022009, considerando 1).
Más adelante, la Corte sostuvo:

El estado de sitio vigente, equivalente al de guerra interna con bandos claramente definidos y con la política de persecución y exterminio de un grupo por razones políticas, ejecutada por agentes estatales, existía a la fecha de comisión del delito de autos y era una realidad contextual a su ejecución; y, es precisamente la que hace aplicables los Convenios de Ginebra y las disposiciones de ius cogens en análisis (Corte Suprema, Rol 5969-2010, considerando 8).

Como puede verse, la aproximación de la Corte Suprema chilena a los supuestos de aplicación del Derecho Internacional Humanitario ha sido bastante precaria. En ninguna de las sentencias examinadas el tribunal consideró los elementos fácticos de aplicación del artículo 3 común a los Convenios de Ginebra. Mientras algunos Ministros de la Corte intentaban aplicar el estándar más exigente del Protocolo II Adicional a los Convenios de Ginebra sin mayor justificación, otros simplemente ignoraban los requisitos de intensidad y organización que, de manera contemporánea a sus decisiones, estaba siendo desarrollado en más detalle por el Tribunal Penal Internacional para la ex Yugoslavia, para determinar la aplicación del artículo 3 común.

Por lo mismo, resulta sorprendente constatar que esta interpretación de la normativa relevante no parece haber sido objeto de mayor crítica en la doctrina chilena. Por una parte, Irigoin Barrenne y Espaliat Larson (2003) han indicado que "la declaración que hace el gobierno chileno en los decretos leyes número 5 y 640 reflejan que existía una situación de conflicto interno que caía dentro de la esfera de aplicación del artículo 3" (p. 161). Por otra parte, Pica (2005) ha indicado que, durante este periodo, en Chile regían los Convenios de Ginebra que impiden dejar sin sanción los crímenes de lesa humanidad y de guerra, como fundamento para justificar la invalidez

(31) Ministro Rubén Ballesteros y abogados integrantes Ricardo Peralta y Hernán Álvarez.

(32) Véase, en ese sentido Corte Suprema, Rol 3125-2004; Corte Suprema, Rol 3452-2006; Corte Suprema, Rol 3587-2005; Corte Suprema, Rol 1528-2006; Corte Suprema, Rol 4662-2007; Corte Suprema, Rol 6212-2007; Corte Suprema, Rol 3907-2007; Corte Suprema, Rol 695-2008; Corte Suprema, Rol 4531-2008; Corte Suprema, Rol 921-2009; Corte Suprema, Rol 3378-2009; Corte Suprema, Rol 1984-2009. 
La aplicación de los Convenios de Ginebra en ausencia de un conflicto armado: El caso de la dictadura militar chilena

The application of the Geneva Conventions in the absence of an armed conflict: The case of the Chilean military dictatorship

del Decreto Ley de Amnistía. Similarmente, Nogueira Alcalá (2005) sostuvo que el Decreto Ley de Amnistía, de aplicarse a graves violaciones a los derechos humanos y/o a crímenes de lesa humanidad, sería contrario a los Convenios de Ginebra. A su vez, Horvitz Lennon (2006) ha indicado que "la declaración de que Chile se encontraba en estado de guerra hizo aplicable el artículo 3 común de los Convenios de Ginebra de 12 de octubre de 1949, referido a los casos de conflictos armados sin carácter internacional que pudieren ocurrir en el territorio de un Estado Parte" (p. 221).

En términos opuestos, Collins (2013) reconoce que la aplicación de los Convenios de Ginebra ha tenido lugar "a pesar de la inexistencia real de un conflicto bilateral que reunía las condiciones de un conflicto interno reconocible en el Derecho Internacional, en virtud de que el régimen dictatorial sí había decretado la existencia de tal estado de cosas como justificación por imponer estados de excepción y de sitio" (p. 96). De igual manera, Zalaquett (2007) señaló que al momento de la publicación del Decreto Ley $\mathrm{N}^{\circ} 5$-el 22 de setiembre de 1973- no existía un conflicto armado interno, y que la dictadura "se valió de una ficción o argucia para facilitar la represión judicial de los disidentes políticos y agravar sus consecuencias procesales y penales" (p. 192). A nivel internacional, Moir (2004) también ha señalado que en Chile no existía un conflicto armado, aunque sin otorgar una mayor justificación.

Por otra parte, Salinas (2007) ha sostenido que el Decreto Ley 5 no era suficiente para determinar la aplicabilidad del Derecho Internacional Humanitario, puesto que la misma dependía de la existencia de situaciones objetivas derivadas de elementos fácticos. Sin embargo, el mismo establece criterios bastante exigentes para la aplicación de los Convenios de Ginebra:

1) Que la parte en rebelión contra el Gobierno legítimo posea una fuerza militar organizada, una autoridad responsable de sus actos, que actúe sobre un territorio determinado y tenga los medios para respetar y hacer respetar los Convenios;

2) Que el Gobierno legítimo esté obligado a recurrir al ejército regular para combatir a los insurrectos, que han de estar organizados militarmente y disponer de una parte del territorio nacional;

3) Que el Gobierno legal haya reconocido a los insurrectos la condición de beligerantes o bien solamente con miras a la aplicación de los Convenios;

4) Que el conflicto se haya incluido en el orden del día del Consejo de Seguridad o de la Asamblea General de las Naciones Unidas como constitutivo de una amenaza contra la paz internacional, una ruptura de la paz o un acto de agresión;

5) Que los insurrectos tengan un régimen que presente las características de un Estado;
6) Que las autoridades civiles de los insurrectos ejerzan el poder de facto sobre la población de una fracción determinada del territorio nacional;

7) Que las fuerzas armadas estén a las órdenes de una autoridad organizada y estén dispuestas a conformarse a las leyes y costumbres de la guerra y;

8) Que las autoridades civiles de los insurrectos reconozcan que están obligadas por las disposiciones del Convenio (pp. 103-104).

Los criterios examinados por Salinas han sido efectivamente considerados por el CICR y otros órganos internacionales en sus decisiones. Sin embargo, debe tenerse presente que el Comité (2020) ha sido enfático en señalar que ellos son elementos útiles para distinguir un conflicto armado de un acto de bandidaje o una insurrección no organizada, pero que no constituyen requisitos obligatorios.

En todo caso, Salinas tiene razón al criticar la aproximación de la Corte Suprema, que yerra en su aplicación de los Convenios de Ginebra. El Derecho Internacional aplicable a los conflictos armados no internacionales no considera que la mera declaración de guerra interna sea suficiente para gatillar la aplicación del artículo 3 común. Como ya se ha explicado, la jurisprudencia ha exigido la verificación de elementos asociados a la organización de los grupos y la intensidad de las hostilidades que difícilmente se podían acreditar durante la dictadura militar chilena.

En este sentido, es relevante destacar que el Derecho Humanitario sí ha admitido la mera declaración de guerra como un elemento suficiente para su aplicación, pero exclusivamente respecto de los conflictos armados internacionales. En ese sentido, el artículo 2 común a los Convenios de Ginebra indica que dichos tratados internacionales se aplicarán "en caso de guerra declarada", sin exigir necesariamente la existencia de enfrentamientos armados. Al respecto, el Comité Internacional de la Cruz Roja (2020) ha indicado que la aplicación de los Convenios en estos casos sirve un propósito humanitario, pues permite que civiles que se encuentren en el territorio de un país enemigo puedan beneficiarse 
inmediatamente de la protección que deriva del IV Convenio de Ginebra, sin requerir el inicio de las hostilidades.

Dicha lógica, sin embargo, no resulta igualmente aplicable a los conflictos armados no internacionales. En ausencia de la aplicación del Derecho Internacional Humanitario, las personas se encuentran protegidas por el régimen del Derecho Internacional de los Derechos Humanos, que en la mayoría de los aspectos otorga una protección más robusta que el primero $^{(33)}$. En términos elementales, y como reconoce el Comité Internacional de la Cruz Roja (2015), "las normas del DIH sobre la conducción de las hostilidades reconocen que el uso de fuerza letal es inherente a la guerra", mientras que en el Derecho Internacional de los Derechos Humanos, "el uso de la fuerza debe ser el último recurso para proteger la vida, cuando los demás medios sean ineficaces o no prometan alcanzar el resultado esperado; además, debe ser estrictamente proporcional al objetivo legítimo que se haya definido" (pp. 3940). En ese sentido, O'Connell (2013) explica que "el Derecho Internacional Humanitario despenaliza la privación de la vida en algunas circunstancias que constituirían un delito en tiempos de paz" (p. 13) $)^{(34)}$.

En suma, a diferencia del derecho aplicable a los conflictos armados internacionales, donde la inmediata aplicación del Derecho Humanitario tras la declaración de una guerra (incluso si ella no viene acompañada de enfrentamientos entre ambos Estados) se justifica para lograr una mayor protección, la aplicación del Derecho Internacional Humanitario ante la mera declaración de una guerra interna tiene el efecto exactamente contrario en los conflictos armados no internacionales: disminuir la protección de los civiles. Es por ello que el derecho aplicable a los CANI no comienza a regir con la existencia de la declaración, sino que requiere la verificación de un umbral asociado, como ya se vio, a los elementos de intensidad y organización.

\subsection{Una lectura alternativa: non venire contra factum proprium}

Como se ha explicado, la interpretación realizada por la Corte Suprema sobre el derecho aplicable y su decisión de aplicar la normativa del Derecho Internacional Humanitario a los hechos ocurridos en Chile -fundada exclusivamente en la declaración de guerra contenida en el Decreto Ley 5 y no en la verificación de los elementos de organización e intensidad-, resulta no solo contraria a la regulación internacional en esta materia -que no reconoce la declaración de guerra como un elemento suficiente en los conflictos armados no internacionales-, sino que incluso se traduce en una menor protección para las personas.

Ahora bien, existe una serie de casos en que la Corte Suprema, si bien ha mantenido la tesis sobre los efectos del Decreto Ley 5 como un reconocimiento legislativo del estado de guerra, ha complementado dicho argumento presentando una tesis que parece basarse en la doctrina de los actos propios o el estoppel y que resulta interesante de examinar. En ese sentido, la Corte Suprema ha indicado:

No es dable que los mismos que se asilaron en las ventajas que les concedía la referida declaración de estado de guerra, establecido por el único instrumento legislativo disponible luego de haberse producido el quebrantamiento de la institucionalidad constitucional vigente hasta entonces, pretendan ahora desconocer su valor para ignorar las sanciones que a las transgresiones de las leyes de tal estado y las limitaciones que a la autoexoneración respecto de ellas imponen los Convenios de Ginebra y los otros instrumentos internacionales ya entonces en vigor sobre la materia. Si valiéndose de la superioridad de la fuerza se consagró un estado de guerra para facilitar la lucha contra los que se oponían al gobierno militar, hay que estarse también a las consecuencias que se siguen de haber vulnerado la normativa que regulan los conflictos bélicos en relación con el tratamiento de los combatientes, a los que ya no se podía considerar como delincuentes comunes y, mucho menos, hacer víctima de represiones brutales como aquella de que dan cuenta los antecedentes de este proceso (Corte Suprema, Rol 3125-2004, considerando 13) $)^{(35)}$.

Asimismo, la Corte ha señalado que dado que el Decreto Ley 5 había hecho aplicable la legislación militar y había admitido la competencia de los tribunales militares en tiempo de guerra, jurisdicción que es "reductora de derechos procesales trascendentales para el inculpado", dicha situación de desprotección "[hace] que los Convenios de Ginebra deban aplicarse

(33) Cabe destacar que el Derecho Internacional de los Derechos Humanos también aplica durante los conflictos armados, de manera complementaria al Derecho Internacional Humanitario. Sobre esto, véase Sassòli (2020).

(34) La traducción es propia, original en inglés.

(35) Véase también Corte Suprema, Rol 1528-2006; Corte Suprema Rol 5698-2009; Corte Suprema, Rol 5285-2010; Corte Suprema, Rol 6823-2009. 
La aplicación de los Convenios de Ginebra en ausencia de un conflicto armado: El caso de la dictadura militar chilena

The application of the Geneva Conventions in the absence of an armed conflict: The case of the Chilean military dictatorship

necesariamente como debido contrapeso a esta jurisdicción extralimitada" (Corte Suprema, Rol 3125-2004, considerando $14)^{(36)}$

Si bien es cierto que el Derecho Internacional Humanitario no reconoce la aplicación de los Convenios de Ginebra a un CANI con una mera declaración de guerra interna, el Derecho Internacional sí reconoce la prohibición de contradicción como un principio general del derecho, que emana del principio de la buena fe (Corte Internacional de Justicia, 1984; Kolb, 1998), y se enmarca en la figura anglosajona del estoppel o la doctrina de los actos propios, propia del Derecho romano continental.

En ese sentido, y como lo adelanta la Corte Suprema, el Decreto Ley 5 permitió la actuación de los tribunales militares en tiempo de guerra y la aplicación del Código de Justicia Militar. Como destaca Díaz Tolosa (2006), dicho procedimiento "da a los imputados infinitamente menores garantías procesales que cuando son encausados por tribunales y procedimientos de tiempo de paz" (p. 316). Por ello, la misma Díaz Tolosa (2006) indica que "[s]iendo la jurisdicción penal militar de tiempo de guerra cercenadora de los derechos procesales trascendentales del imputado, deben aplicarse los Convenios de Ginebra como debido contrapeso a esta jurisdicción abusiva, que por ello mismo solo se justifica en caso de guerra" ( $p$. 319). De esta manera, el argumento supone que los agentes de la dictadura militar chilena, que se beneficiaron del régimen menos protector establecido mediante la aprobación del Decreto Ley 5 , no pueden ahora negar que dicho régimen era en efecto aplicable cuando el mismo resulta perjudicial a sus intereses.

El argumento es original, pero no termina de ser convincente. La figura del estoppe/ supone que es el mismo individuo, entidad o Estado quien contradice su conducta previa, y contraviene así el principio fundamental de la buena fe. Resulta cuestionable, sin embargo, que dicha doctrina sea aplicable en este caso. Fue la Junta de Gobierno la que promulgó el Decreto Ley 5 , declarando el estado de guerra interna. No parece haber mayor justificación para imponer un deber de no contradicción a agentes estatales $u$ otros individuos que no participaron en la discusión o adopción de dicho decreto, incluso si algunos se beneficiaron indirectamente del mismo.

En cualquier caso, incluso si se aceptara que la prohibición de la contradicción entrega una posibilidad de invocación del Derecho Internacional Humanitario, esta debería estar limitada al ámbito de aplicación de los conflictos armados no internacionales. Sin embargo, como se explicará en la sección siguiente, la Corte Suprema ha ido mucho más lejos en su análisis, invocando sin mayor justificación normas de los Convenios de Ginebra que tienen un ámbito de aplicación exclusivo para los conflictos armados internacionales.

\subsection{Los Convenios de Ginebra más allá del artículo 3 común}

Como se explicaba en el segundo capítulo de este trabajo, el Derecho Internacional Humanitario cuenta con una distinta regulación convencional para conflictos armados internacionales y no internacionales. Así, mientras que la totalidad de los cuatro Convenios de Ginebra y el Protocolo I Adicional (con sus 102 artículos) regulan los conflictos armados internacionales, los conflictos armados no internacionales se encuentran solo regidos por lo dispuesto en el artículo 3 común a los Convenios de Ginebra, y el mucho más reducido Protocolo II Adicional (con apenas 28 artículos). Por otra parte, en lo relativo al Derecho Consuetudinario, si bien el Comité Internacional de la Cruz Roja ha sostenido que los regímenes de los CAI y CANI se encuentran en proceso de acercamiento, con normas que resultarían aplicables con independencia de la clasificación del conflicto (Henckaerts \& Doswald-Beck, 2005)(37), esa posición ha sido criticada por parte de la doctrina (Bellinger \& Haynes, 2007; Dinstein, 2014). De hecho, incluso quienes sostienen que sería preferible contar con un régimen único que no distinga entre los tipos de conflictos armados, reconocen que aún no se ha llegado a dicho estado (Crawford, 2007).

Dicha diferencia, sin embargo, no ha sido considerada por la Corte Suprema. Por ejemplo, en el ya referido caso del homicidio de miembros de MIR en Choshuenco, y tras señalar que la situación chilena se encontraba regida por la normativa aplicable a los conflictos armados no internacionales, la Corte indicó que la decisión de primera instancia que declaraba prescrita la acción

(36) Véase también Corte Suprema, Rol 3125-2004.

(37) Según el estudio del CICR, de 161 normas de Derecho Internacional Humanitario Consuetudinario identificadas, 140 aplicarían a CANI (y 8 posiblemente también podrían aplicar a CANI). 
penal era contraria, entre otras normas, a los artículos 147 y 148 del IV Convenio de Ginebra relativo a la protección de la población civil (Corte Suprema, Rol 559-2004).

En una serie de otras decisiones, y tras reconocer que la normativa aplicable a los conflictos armados no internacionales era el artículo 3 común, la Corte Suprema hizo referencia los artículos 105 y siguientes del III Convenio de Ginebra, y a los artículos 146, 147 y 148 del IV Convenio -todas ellas normas que resultan aplicables exclusivamente a los conflictos armados internacionales-, para desestimar la aplicación del Decreto Ley de Amnistía y/o sostener la imprescriptibilidad de los crímenes ${ }^{(38)}$. A mayor abundamiento, la Corte Suprema también ha hecho referencia a otras normas que son exclusivamente aplicables a conflictos armados internacionales, como la III Convención de La Haya relativa a las leyes y costumbres de la guerra terrestre, y el Protocolo I Adicional de los Convenios de Ginebra (Corte Suprema, Rol 5436-2010).

La doctrina chilena no ha examinado este asunto en mayor detalle. Si bien Salinas (2007) ha criticado que la Corte Suprema no distinga entre las normas aplicables a los CAI y los CANI, otros académicos no parecen encontrar un problema en la aproximación de la Corte Suprema. Así, el profesor Nogueira Alcalá (2006) también ha hecho referencia al artículo 146 del IV Convenio de Ginebra como normativa aplicable a la situación chilena, y ha sostenido que el Decreto Ley 2191 de Amnistía supone una vulneración abierta y flagrante de los Convenios de Ginebra. Igualmente lo ha hecho Matus (2006), con varias referencias al III y IV Convenio de Ginebra. Por su parte, Horvitz Lennon (2006) parece también ser favorable a dicha aproximación, puesto que indica que la tendencia internacional "es a equiparar el tratamiento del conflicto interno al paradigma del conflicto bélico de carácter internacional, reconduciéndolo a un mismo esquema normativo de atribución de responsabilidades del Estado por la infracción de las normas que regulan los conflictos armados" (p. 221). Resulta peculiar, sin embargo, que uno de los fundamentos entregados por Horvitz Lennon sea el desarrollo que significó el Estatuto de Roma de la Corte Penal Internacional, toda vez que dicha adopción es muy posterior a los hechos que tuvieron lugar durante la dictadura militar chilena, y por lo demás, el mismo sigue manteniendo una distinción relevante entre crímenes cometidos en CAI y en CANI(39).
En cualquier caso, incluso de ser efectiva la cercanía entre ambos regímenes jurídicos, y en caso de poder sostenerse que el Derecho Internacional Humanitario también prohíbe las amnistías y la aplicación de la prescripción, no debe perderse de vista que dicha cercanía tiene lugar por medio de la aplicación del Derecho Internacional Consuetudinario, y no por una importación de reglas convencionales de un tipo de conflicto a otro. Los artículos citados del III y IV Convenio de Ginebra sin duda no son aplicables a los CANI, cuestión distinta es determinar si la norma subyacente ha adquirido el carácter de norma consuetudinaria aplicable a conflictos armados no internacionales. Si bien las Normas 159 y 160 del estudio del Comité Internacional de la Cruz Roja indican que la prohibición de amnistía de crímenes de guerra y la no aplicación de las normas de prescripción aplicaría también a los CANI como costumbre internacional (Henckaerts \& Doswald-Beck, 2005), es necesario determinar que las normas habían adquirido ese carácter al momento de la comisión de los hechos, no bastando que tuviera tal carácter al momento del juicio. Nada de ello se encuentra en el examen realizado por la Corte Suprema.

\section{La alternativa: EI Derecho Internacional de los Derechos Humanos}

Como se ha explicado hasta ahora, la Corte Suprema chilena cuenta con una abultada jurisprudencia relativa a la aplicación del Derecho Internacional Humanitario a los hechos que tuvieron lugar en Chile entre 1973 y 1990 . Sin embargo, resulta cuestionable que la situación fáctica que estaba siendo analizada cumpliera con el umbral mínimo para la existencia de un

(38) Corte Suprema, Rol 2666-04; Corte Suprema, Rol 1528-2006; Corte Suprema, Rol 6188-2006; Corte Suprema, Rol 1489-2007; Corte Suprema, Rol 1528-2006; Corte Suprema, Rol 6212-2007; Corte Suprema, Rol 4662-2007; Corte Suprema, Rol 3907-2007; Corte Suprema, Rol 4691-2007; Corte Suprema, Rol 695-2008; Corte Suprema, Rol 4531-2008; Corte Suprema, Rol 921-2009; Corte Suprema, Rol 3378-2009; Corte Suprema, Rol 1984-2009; Corte Suprema, Rol 5720-2010; Corte Suprema, Rol 30598-2014; Corte Suprema, Rol 8706-2015; Corte Suprema, Rol 27627-2019.

(39) Compárese para estos efectos el artículo 8.2(a) y 8.2(b) del Estatuto de Roma, que establecen los crímenes de guerra aplicables a conflictos armados internacionales, con el artículo 8.2(c) y 8.2.(e) del mismo Estatuto, que establece una lista mucho más reducida de crímenes de guerra aplicables a conflictos armados no internacionales. 
La aplicación de los Convenios de Ginebra en ausencia de un conflicto armado: El caso de la dictadura militar chilena

The application of the Geneva Conventions in the absence of an armed conflict: The case of the Chilean military dictatorship

conflicto armado no internacional, que requiere una cierta intensidad de las hostilidades y organización de los grupos involucrados. Si bien la conclusión fáctica aquí formulada es esencialmente preliminar, puesto que requiere un análisis más profundo de los eventos históricos relevantes, no hay duda de que el análisis realizado por los tribunales superiores de justicia en Chile no ha considerado ninguno de estos elementos, ni ha entregado elementos que permitan dar por verificado el umbral de los CANI, limitándose a hacer referencia al Decreto Ley 5 sin explicar por qué este es suficiente para hacer aplicable el Derecho Internacional Humanitario. En su mejor versión, la Corte Suprema ha dado aplicación al principio de prohibición de contradicción -cuya relevancia para los casos resulta a lo menos controversial-, pero ha hecho caso omiso a aspectos fundamentales del Derecho Internacional Humanitario, como la diferencia en el derecho aplicable a los conflictos armados internacionales y los conflictos armados no internacionales.

Lo anterior, sin embargo, no significa que el Decreto Ley de Amnistía deba ser aplicable a los hechos ocurridos en la dictadura militar chilena, o que la prescripción deba servir como una barrera a la persecución penal de estos hechos. En efecto, descartada la aplicación de las normas de los Convenios de Ginebra, resta preguntarse si existía otra alternativa para la Corte Suprema que fuera compatible con las normas del Derecho Internacional.

En lo que sigue, se esbozan algunas alternativas que permitirían a los tribunales chilenos juzgar a aquellos individuos responsables por graves crímenes internacionales, aplicando el estatuto normativo adecuado. Como ya se adelantaba, sostener que un periodo histórico no se encuentra gobernado por las normas de Derecho Internacional Humanitario no supone, en caso alguno, afirmar que no existe protección internacional para las víctimas. Por el contrario, es precisamente ahí donde cobra especial relevancia el Derecho Internacional de los Derechos Humanos, que otorga una protección más robusta a las víctimas, y que sí opera en casos de disturbios internos como los ocurridos en Chile.

Esta propuesta no es, por cierto, realmente novedosa: la Corte Suprema ya ha considerado el Derecho Internacional de los Derechos Humanos en sus decisiones. Sin embargo, lo ha hecho confundiéndolo con el Derecho Internacional Humanitario, como si ambos se trataran de la misma rama del Derecho Internacional. Por ejemplo, la Corte ha señalado que la obligación de respetar y promover los derechos humanos deriva del artículo 1 de los Convenios de Ginebra(40). En otras oportunidades, la Corte Suprema ha indicado que los Convenios de Ginebra forman parte de la normativa internacional de derechos humanos $^{(41)}$.

Dicha confusión conceptual no es irrelevante. Como se adelantaba, la aplicación del Derecho Internacional Humanitario supone una menor protección para las personas frente a los hechos de violencia. La decisión de la Corte Suprema presenta así un problema doble: por una parte, la invocación del Derecho Internacional Humanitario presenta impropiamente los hechos ocurridos en la dictadura como una oposición entre fuerzas armadas y grupos organizados en un estado de guerra, en circunstancias que la historia señala que el periodo se corresponde más bien con un "estado de terror" (Correa et al., 2001, p. 281). En efecto, durante la dictadura militar, la violencia estatal no fue respuesta y resultado de un enfrentamiento con grupos no estatales, sino un caso de terrorismo de Estado y represión injustificada y brutal. Por otra parte, y aún más grave, la aplicación del Derecho Internacional Humanitario por la Corte Suprema disminuye la protección de los miembros de grupos de resistencia, que ya no gozarían de la plenitud de la protección del Derecho Internacional de los Derechos Humanos, sino que podrían ser blancos legítimos de violencia en su calidad de supuestos combatientes.

Es precisamente esta menor protección que entrega el Derecho Internacional Humanitario la que explica que la posición de la guerra interna no solo sea la postura adoptada por la Corte Suprema sino también por las Fuerzas Armadas -incluso tras el retorno la democracia-, en tanto ella le permitía justificar parciamente los hechos de violencia. Por ejemplo, el Ejército de

(40) Véase en ese sentido Corte Suprema, Rol 1528-2006; Corte Suprema, Rol 921-2009; Corte Suprema, Rol 3378-2009; Corte Suprema, Rol 1984-2009; Corte Suprema, Rol 9474-2009.

(41) Véase en ese sentido Corte Suprema, Rol 6823-2009; Corte Suprema, Rol 31945-2014; Corte Suprema, Rol 17015-2015; Corte Suprema, Rol 173-2016; Corte Suprema, Rol 20567-2015; Corte Suprema, Rol 20166-2015; Corte Suprema, Causa Rol 340572016; Corte Suprema, Rol 28581-2016; Corte Suprema, Rol 44074-2016; Corte Suprema, Rol 7947-2017; Corte Suprema, Rol 39732-2017; Corte Suprema, Rol 2458-2018; Corte Suprema, Rol 2458-2018. 
Chile, en su presentación a la Comisión Nacional de Verdad y Reconciliación, señaló que Chile vivía un estado de guerra civil. Entre los factores que el Ejército consideró más relevantes para detectar la existencia de una guerra civil, se incluyó: "víctimas fatales y heridos en todos los sectores; familias divididas, una economía devastada, los poderes públicos superados por los acontecimientos y en definitiva el restablecimiento de la paz y del imperio de derecho mediante el uso de la fuerza por parte de sus legítimos detentadores: Las Fuerzas Armadas y Carabineros de Chile" (citado en Díaz Tolosa, 2006, p. 314). Más allá de que los factores mencionados no cumplen con los elementos ya examinados de los CANI, el discurso no es neutral y el uso de los términos tiene un objetivo claro: la referencia a la guerra busca intentar igualar los hechos de violencia de ambos lados -en circunstancias que jamás fueron equivalentes- y legitimar el actuar de las Fuerzas Armadas y de Orden.

Pues bien, a pesar de hacer referencias al Derecho Internacional de los Derechos Humanos y a los crímenes de lesa humanidad en sus decisiones, la Corte Suprema parece considerar que estos estatutos normativos están irremediablemente vinculados a la existencia de un conflicto armado. Así se explica que la Corte sostenga que, en caso de no aplicar el artículo 3 común y considerarse que el caso corresponde a disturbios internos, el gobierno tendría derecho "a dejar a los heridos sin asistencia, a infligir torturas o mutilaciones o a realizar ejecuciones sumarias" (Corte Suprema, Rol 6212-2007, considerando 9) ${ }^{(42)}$.

Similar confusión se identifica en la doctrina. Así, Díaz Tolosa (2006) indica que "no hay razón alguna -ni aun la baja intensidad de los enfrentamientos- para dejar afuera todo principio humanitario, pues de ser así habría que resignarse al abandono completo de la exigencia mínima de humanidad en los conflictos bélicos, que constantemente ha inspirado el Derecho Internacional Humanitario" (p. 322). En consecuencia, señala que incluso en casos de tensiones o disturbios internos, los Convenios de Ginebra o al menos sus principios generales deberían aplicarse en su calidad de normas intransgredibles de Derecho Internacional Consuetudinario, y en particular la protección mínima del artículo 3 común a los Convenios de Ginebra, sosteniendo además también que las normas de Derecho Internacional Humanitario deberían aplicarse por analogía. La misma idea es reiterada por la misma autora en otra publicación, donde sostiene que si bien el Derecho Internacional Humanitario opera en casos de conflicto armado, "ciertas normas del DIH, por ser normas de Derecho Consuetudinario y de Derecho Internacional general con la categoría de ius cogens internacional, cuyos principios fundantes son de aplicación imperativa, general y universal, debieran aplicarse en el foro interno de los Estados no solo en tiempos de belicosidad, sino también en tiempos de paz, en caso de violación de derechos fundamentales" (Díaz Tolosa, 2012, p. 282).

La posición de Díaz Tolosa se justificaría si no existiera otro régimen aplicable. Pero como ya se adelantaba, y considerando que el Derecho Internacional de los Derechos Humanos no solo es pertinente, sino que otorga mayor protección que el Derecho Internacional Humanitario, la aplicación por analogía de este último régimen legal resulta no solo innecesaria sino incluso contraproducente. Por lo demás, la referencia a que el Derecho Humanitario debería aplicarse como Derecho Consuetudinario resulta difícil de entender: en su dimensión de costumbre internacional, el Derecho Humanitario se encuentra igualmente limitado a la aplicación en circunstancias de conflictos armados.

Como se ha adelantado, existe un camino alternativo: la Corte Suprema puede y debe examinar el Derecho Internacional de los Derechos Humanos de manera autónoma, y de esta manera determinar si existe alguna regulación que prohíba la aplicación de la prescripción y/o de la amnistía respecto de crímenes cometidos fuera del contexto de un conflicto armado. El candidato más próximo es la regulación de los crímenes de lesa humanidad. De hecho, la misma Corte Suprema ha calificado los hechos que tuvieron lugar en la dictadura como crímenes de lesa humanidad -aun cuando lo ha hecho invocando erróneamente los Convenios de Ginebra, que se vinculan más bien con los crímenes de guerra ${ }^{(43)}$.

(42) Véase, en el mismo sentido, Corte Suprema, Rol 3907-2007; Corte Suprema, Rol 695-2008; Corte Suprema, Rol 921-2009; Corte Suprema, Rol 3378-2009.

(43) Véase Corte Suprema, Rol 1528-2006; Corte Suprema, Rol 6212-2007; Corte Suprema, Rol 4691-2007; Corte Suprema, Rol 695-2008; Corte Suprema, Rol 921-2009; Corte Suprema, Rol 3378-2009; Corte Suprema, Rol 1984-2009; Corte Suprema, Rol 11983-2014; Corte Suprema, Rol 32454-2014; Corte Suprema, Rol 14283-2015; Corte Suprema, Rol 173-2016; Corte Suprema, Rol 20567-2015; Corte Suprema, Rol 2458-2018. 
La aplicación de los Convenios de Ginebra en ausencia de un conflicto armado: El caso de la dictadura militar chilena

The application of the Geneva Conventions in the absence of an armed conflict: The case of the Chilean military dictatorship

Pues bien, existe un amplio desarrollo jurisprudencial y doctrinario a nivel internacional que permitiría, por ejemplo, sustentar la inaplicabilidad de la auto-amnistía respecto de estos crímenes internacionales o no admitir la aplicabilidad de la prescripción, sin necesidad de sostener la existencia de un conflicto armado. De hecho, la Corte Interamericana de Derechos Humanos lo ha señalado expresamente en varias oportunidades. En el caso Barrios Altos vs. Perú (2001), la Corte señaló que "son inadmisibles las disposiciones de amnistía, las disposiciones de prescripción y el establecimiento de excluyentes de responsabilidad que pretendan impedir la investigación y sanción de los responsables de las violaciones graves de los derechos humanos tales como la tortura, las ejecuciones sumarias, extralegales o arbitrarias y las desapariciones forzadas, todas ellas prohibidas por contravenir derechos inderogables reconocidos por el Derecho Internacional de los Derechos Humanos" (párr. 41). Asimismo, en Hermanos Gómez Paquiyauri vs. Perú (2004), la Corte indicó que "el Estado deberá abstenerse de recurrir a figuras como la amnistía, la prescripción y el establecimiento de excluyentes de responsabilidad, así como medidas que pretendan impedir la persecución penal o suprimir los efectos de la sentencia condenatoria" (párr. 232).

Más adelante, y en el caso particular de la situación chilena, la Corte Interamericana indicó que las leyes de amnistía con las características de la chilena "conducen a la indefensión de las víctimas y a la perpetuación de la impunidad de los crímenes de lesa humanidad, por lo que son manifiestamente incompatibles con la letra y el espíritu de la Convención Americana e indudablemente afectan derechos consagrados en ella" (Almonacid Arellano vs. Chile, 2006, párr. 119). Por ello, la Corte indicó que el Decreto Ley de Amnistía "carece de efectos jurídicos" (Almonacid Arellano vs. Chile, 2006, párr. 145). Por su parte, en lo que respecta a la prescripción, la Corte indicó que "el Estado no podrá argumentar prescripción [...] para excusarse de su deber de investigar y sancionar a los responsables" (Almonacid Arellano vs. Chile, 2006, párr. 141).

Esta posición ha sido compartida por la doctrina. Por ejemplo, Ambos (1999) ha indicado que una autoamnistía, "es a todo evento violatoria del Derecho Internacional” (p. 130). En términos similares, Werle \& Jeberger (2014) han indicado que "las amnistías generales por crímenes de Derecho Internacional son inadmisibles según el Derecho Internacional Consuetudinario"(44).

Desde otra perspectiva, Jackson (2007) ha adoptado una visión más crítica, que rechaza las afirmaciones generales sobre la ilegalidad de las amnistías. Crucialmente, Jackson no considera que todas las amnistías estén prohibidas por el Derecho Internacional de los Derechos Humanos, en tanto ellas podrían eventualmente estar justificadas como una hipótesis de derogación del deber de perseguir, admisible en casos de emergencia pública bajo el mismo régimen del Derecho Internacional de los Derechos Humanos. Sin embargo, en el caso chileno, Jackson sostiene que la autoamnistía chilena no cumpliría con esos requisitos, y, en consecuencia, sería ilegal y acarrearía la responsabilidad del Estado por no cumplir con el deber, derivado del Derecho Consuetudinario, de perseguir estos crímenes internacionales.

El análisis aquí presentado sobre el Derecho Internacional de los Derechos Humanos y las obligaciones de los Estados relativo a la persecución de crímenes internacionales requiere un estudio más extenso que el que aquí puede formularse. Suficiente es señalar que existen buenos antecedentes que permitirían a los tribunales chilenos dejar sin efecto la auto-amnistía y no considerar la prescripción sin necesidad de acudir a la normativa de los Convenios de Ginebra u otras normas de Derecho Internacional Humanitario. Si bien existen decisiones de la Corte Suprema en ese sentido (Corte Suprema, Rol 24558), también continúan existiendo referencias a los Convenios de Ginebra en fallos más recientes, que insisten en aplicar este régimen jurídico a los hechos que tuvieron lugar durante la dictadura militar chilena (Corte Suprema, Rol 33547-2018).

Como se ha sostenido en este artículo, la aplicación de la normativa del Derecho Internacional de los Derechos Humanos y la figura de los crímenes de lesa humanidad permite no solo una mayor protección de las víctimas, sino que presenta un análisis jurídico que puede ser consistente con la realidad de los hechos de violencia. Como ya se explicaba, invocar el Derecho Internacional Humanitario supone utilizar un régimen jurídico que presupone la existencia de una cierta equivalencia entre las fuerzas que se enfrentan, y la autorización del uso de fuerza letal contra los enemigos. La situación chilena, en cambio, se corresponde más con una represión unilateral, con violencia de amplio alcance y que no se condecía con la necesidad de reaccionar ante una resistencia organizada. $\mathrm{Al}$ igual que el reconocimiento de la verdad histórico, es necesario también que el derecho refleje adecuadamente esa realidad.

(44) Traducción propia, original en inglés. 


\section{Referencias bibliográficas}

Akande, D. (2019). La clasificación de los conflictos armados: los conceptos jurídicos relevantes. Revista Latinoamericana de Derecho Internacional, 8, 77-144.

Álvarez, R. (2008). Aún tenemos patria, ciudadanos. El Partido Comunista de Chile y la salida no pactada de la dictadura (1980-1988). En V. Valdivia, R. Álvarez, J. Pinto, K. Donoso \& S. Leiva (eds.), Su revolución contra nuestra revolución. Vol. II. La pugna marxistagremialista en los ochenta (pp. 19-82).

Ambos, K. (1999). Impunidad y Derecho Penal Internacional. Ad-Hoc.

Bellinger, J. \& Haynes W. (2007). A US government response to the International Committee of the Red Cross study Customary International Humanitarian Law. International Review of the Red Cross, 89(866), 443-471.

Cavallo, A., Salazar, M. \& Sepúlveda, O. (1997). La historia oculta del régimen militar: memoria de una época, 1973-1988. Grijalbo.

Collins, C. (2013). Chile a más de dos décadas de justicia de transición. Política / Revista de Ciencia Política, 51(2), 79-113.

Comisión Nacional de Verdad y Reconciliación. (1996). Informe de la Comisión Nacional de Verdad y Reconciliación (Comisión Rettig). Corporación Nacional de la Reparación y Reconciliación.

Comisión Nacional sobre Prisión Política y Tortura. (2004). Informe de la Comisión Nacional sobre Prisión Política y Tortura (Comisión Valech I).

Comisión Nacional sobre Prisión Política y Tortura. (2005). Nómina de personas reconocidas como víctimas en etapa de reconsideración.

Comisión Presidencial Asesora para la Calificación de Detenidos Desaparecidos, Ejecutados Políticos y Víctimas de Prisión Política y Tortura. (2011). Informe de la Comisión (Comisión Valech II).

Comité Internacional de la Cruz Roja [CICR]. (1971). Document V: Protection of victims of non-international armed conflicts. Conference of Government Experts on the Reaffirmation and Development of International Humanitarian Law Applicable in Armed Conflicts. Disponible en: https://www.loc.gov/rr/frd/Military_Law/pdf/RCconference_Vol-5.pdf

Comité Internacional de la Cruz Roja [CICR]. (1978). Protection and assistance in situations not covered by international humanitarian law. International Review of the Red Cross, 18(205), 210-214.

Comité Internacional de la Cruz Roja [CICR]. (1987). Commentary on Protocol II Additional to the Geneva Conventions of 12 August 1949, and relating to the Protection of Victims of Non-International Armed Conflicts. https://ihl-databases.icrc.org/applic/ihl/ihl.nsf/INTRO/475

Comité Internacional de la Cruz Roja [CICR]. (2014). The International Committee of the Red Cross's (ICRC's) role in situations of violence below the threshold of armed conflict. International Review of the Red Cross, 96(893), 275-304.

Comité Internacional de la Cruz Roja [CICR]. (2015). Derecho Internacional Humanitario: Respuestas a sus preguntas.

Comité Internacional de la Cruz Roja [CICR]. (2020). Commentary on the Third Geneva Convention relative to the
Treatment of Prisoners of War. https://ihldatabases.icrc.org/applic/ihl/ihl.nsf/Treaty. xsp?documentld=77CB9983BE01D004C12563 CD002D6B3E\&action=openDocument

Corporación Nacional de Reparación y Reconciliación. (1996). Informe sobre la calificación de víctimas de violaciones a los derechos humanos y de la violencia política.

Correa, S., Figueroa, C., Jocelyn-Holt, A., Rolle, C. \& Vicuña, M. (2001). Historia del siglo XX chileno. Editorial Sudamericana.

Corte Interamericana de Derechos Humanos. (2001, 14 de marzo). Caso Barrios Altos vs. Perú.

Corte Interamericana de Derechos Humanos. (2004, 8 de julio). Caso de los Hermanos Gómez Paquiyauri vs. Perú.

Corte Interamericana de Derechos Humanos. (2006, 26 de setiembre). Caso Almonacid Arellano y otros vs. Chile.

Corte Internacional de Justicia. (1984): Delimitation of the Maritime Boundary in the Gulf of Maine Area, Judgment, I.C.J. Reports.

Corte Suprema de Chile. (1996, 3 de diciembre). Sentencia Causa Rol 263-96.

Corte Suprema de Chile. (2005, 4 de agosto). Sentencia Causa Rol 457-2005.

Corte Suprema de Chile. (2006, 13 de diciembre). Sentencia Causa Rol 559-2004.

Corte Suprema de Chile. (2007, 18 de enero). Sentencia Causa Rol 2666-04.

Corte Suprema de Chile. (2007, 13 de marzo). Sentencia Causa Rol 3125-2004.

Corte Suprema de Chile. (2007, 10 de mayo). Sentencia Causa Rol 3452-2006.

Corte Suprema de Chile. (2007, 13 de noviembre). Sentencia Causa Rol 6188-2006.

Corte Suprema de Chile. (2007, 27 de diciembre). Sentencia Causa Rol 1489-2007.

Corte Suprema de Chile. (2007, 27 de diciembre). Sentencia Causal Rol 3587-2005.

Corte Suprema de Chile. (2007, 27 de diciembre). Sentencia Causa Rol 3925-2005.

Corte Suprema de Chile. (2008, 24 de enero). Sentencia Causa Rol 1528-2006.

Corte Suprema de Chile. (2008, 13 de mayo). Sentencia Causa Rol 3872-2007.

Corte Suprema de Chile. (2008, 25 de setiembre). Sentencia Causa Rol 4662-2007.

Corte Suprema de Chile. (2008, 29 de octubre). Sentencia Causa Rol 6212-2007. 
La aplicación de los Convenios de Ginebra en ausencia de un conflicto armado: El caso de la dictadura militar chilena

The application of the Geneva Conventions in the absence of an armed conflict: The case of the Chilean military dictatorship

Corte Suprema de Chile. (2009, 21 de enero). Sentencia Causa Rol 3907-2007.

Corte Suprema de Chile. (2009, 28 de enero). Sentencia Causa Rol 4691-2007.

Corte Suprema de Chile. (2009, 9 de marzo). Sentencia Causa Rol 695-2008.

Corte Suprema de Chile. (2009, 25 de marzo). Sentencia Causa Rol 4531-2008.

Corte Suprema de Chile. (2009, 13 de agosto). Sentencia Causa Rol 921-2009.

Corte Suprema de Chile. (2009, 29 de setiembre). Sentencia Causa Rol 3378-2009.

Corte Suprema de Chile. (2009, 3 de diciembre). Sentencia Causa Rol 1984-2009.

Corte Suprema de Chile. (2010, 18 de mayo). Sentencia Causa Rol 3302-2009.

Corte Suprema de Chile. (2010, 21 de diciembre). Sentencia Causa Rol 9474-2009.

Corte Suprema de Chile. (2011, 25 de enero). Sentencia Causa Rol 5698-2009.

Corte Suprema de Chile. (2011, 22 de junio). Sentencia Causa Rol 5436-2010.

Corte Suprema de Chile. (2011, 11 de julio). Sentencia Causa Rol 5285-2010.

Corte Suprema de Chile. (2011, 25 de agosto). Sentencia Causa Rol 6823-2009.

Corte Suprema de Chile. (2011, 9 de noviembre). Sentencia Causal Rol 5969-2010.

Corte Suprema de Chile. (2012, 7 de marzo). Sentencia Causa Rol 5720-2010.

Corte Suprema de Chile. (2014, 23 de diciembre). Sentencia Causa Rol 11983-2014.

Corte Suprema de Chile. (2015, 29 de abril). Sentencia Causa Rol 24558-2014.

Corte Suprema de Chile. (2015, 21 de julio). Sentencia Causa Rol 32454-2014.

Corte Suprema de Chile. (2015, 1 de diciembre). Sentencia Causa Rol 30598-2014.

Corte Suprema de Chile. (2015, 15 de diciembre). Sentencia Causa Rol 31945-2014.

Corte Suprema de Chile. (2016, 11 de enero). Sentencia Causa Rol 8706-2015.

Corte Suprema de Chile. (2016, 29 de enero). Sentencia Causa Rol $17015-2015$

Corte Suprema de Chile. (2016, 18 de mayo). Sentencia Causa Rol 14283-2015.

Corte Suprema de Chile. (2016, 20 de junio). Sentencia Causa Rol 173-2016.

Corte Suprema de Chile. (2016, 21 de junio). Sentencia Causa Rol 20567-2015.
Corte Suprema de Chile. (2016, 20 de julio). Sentencia Causa Rol 20166-2015.

Corte Suprema de Chile. (2016, 8 de setiembre). Sentencia Causa Rol 27627-2019.

Corte Suprema de Chile. (2016, 6 de octubre). Sentencia Causa Rol 34057-2016.

Corte Suprema de Chile. (2016, 24 de octubre). Sentencia Causa Rol 28581-2016.

Corte Suprema de Chile. (2016, 24 de octubre) Sentencia Causa Rol 44074-2016.

Corte Suprema de Chile. (2017, 12 de setiembre). Sentencia Causa Rol 7947-2017.

Corte Suprema de Chile. (2018, 14 de mayo). Sentencia Causa Rol 39732-2017.

Corte Suprema de Chile. (2019, 25 de julio). Sentencia Causa Rol 2458-2018.

Corte Suprema de Chile. (2021, 23 de agosto). Sentencia Causa Rol 22547.

Crawford, E. (2007). Unequal before the Law: The Case for the Elimination of the Distinction between International and Non-international Armed Conflicts. Leiden Journal of International Law, 20(2), 441-465.

Díaz Tolosa, R. (2006). Aplicación de los Convenios de Ginebra por los tribunales de justicia chilenos. Revista Chilena de Derecho, 33(2), 305-327.

Díaz Tolosa, R. (2012). Aplicabilidad en el ámbito interno y en tiempos de paz de las normas de ius cogens del Derecho Internacional Humanitario. Estudios Constitucionales, 10(2), 281-322.

Dinstein, Y. (2014). Non-International Armed Conflicts in International Law. Cambridge University Press.

El Mercurio. (1987, 17 de junio). 12 muertos en batidas contra el terrorismo.

Galdámez Zelada, L. (2012). Incidencia de los tratados y del ius cogens internacional en el tratamiento de graves violaciones a los derechos humanos en Chile. Revista de Derecho Público, 77, 295-319.

González, M. (2012). La Conjura: Los mil y un días del golpe. Catalonia.

Henckaerts, J-M. \& Doswald-Beck, L. (2005). Customary International Humanitarian Law, Volume I: Rules.

Horvitz, M. (2006). Amnistía y Prescripción en Causas sobre Violación de Derechos Humanos en Chile. Anuario de Derechos Humanos, 2, 217-225.

Irigoin, J. \& Espaliat, A. (2003). Las normas de Derecho Internacional Humanitario que rigen los 
conflictos armados sin carácter internacional: su aplicación en Chile. Estudios Internacionales, 36(143), 151-163.

Jackson, M. (2007). The customary international law duty to prosecute crimes against humanity: A new framework. Tulane Journal of International and Comparative Law, 16(1), 117-156.

Kolb, R. (1998) La bonne foi en droit international public. Revue Belge de Droit International, 31(2), 661-732.

La Cuarta. (1987, 16 de junio). Abatido extremista que se agarró a tunazos con patrulla de seguridad. Diario La Cuarta.

La Haye, E. (2008). War crimes in internal armed conflicts. Cambridge University Press.

La Tercera. (1987, 16 de junio). 4 extremistas mueren a tiros en enfrentamientos.

Matus, J. (2006). Informe sobre la ejecución de la sentencia en el caso Almonacid presentado a la Cámara de Diputados. Ius et Praxis, 12(2), 385-396.

Melzer, N. (2019). Derecho Internacional Humanitario: Una introducción integral. Comité Internacional de la Cruz Roja.

Moir, L. (2004). The Law of Internal Armed Conflict. Cambridge University Press.

Nogueira Alcalá, H. (2005). Decreto Ley de Amnistía 2.191 de 1978 y su armonización con el Derecho Internacional de los Derechos Humanos. Revista de Derecho (Valdivia), 18(2). https:// revistaderechovaldivia.cl/index.php/revde/article/ view/741

Nogueira Alcalá, H. (2006). Informe pericial ante Corte Interamericana de Derechos Humanos sobre Decreto Ley 2191 de Amnistía de fecha 19 de abril de 1978. Revista lus et Praxis, 12(1), 251-274.

O'Connell, M. (2013). Historical Development and Legal Basis. En D. Fleck (ed.), The Handbook of International Humanitarian Law. Oxford University Press.

Pica, R. (2005). La Convención Americana de Derechos Humanos y las autoamnistías de los Estados por violaciones a los derechos humanos, Chile y el caso del DL 2191. Estudios Constitucionales, 3(2), 141-161.

Pinto, J. (2006). ¿Y la historia les dio la razón? EI MIR en dictadura, 1973-1981. En V. Valdivia, R. Álvarez \& J. Pinto (eds.), Su revolución contra nuestra revolución. Izquierdas y derechas en el Chile de Pinochet (1973-1981) (pp. 153-205). LOM Ediciones.

Pinto, J. \& Leiva, S. (2008). Punto de quiebre: EI MIR en los ochenta. En V. Valdivia, R. Álvarez, J. Pinto, K. Donos \& S. Leiva (eds.), Su revolución contra nuestra revolución. Vol. II. La pugna marxistagremialista en los ochenta (pp. 19-82). LOM Ediciones.

Politzer, P. (1988). La ira de Pedro y los otros. Grupo Planeta.

Politzer, P. (2013). Altamirano. Random House Mondadori.

Salinas, H. (2007). Aplicación del Derecho Internacional y caso Choshuenco: Legalidad y seguridad jurídica vulneradas. En A. Fermandois \& J. García, Sentencias Destacadas 2006. Una mirada desde las políticas públicas (pp. 99-125). Libertad y Desarrollo.

Salmón, E. (2016). Introducción al Derecho Internacional Humanitario. Instituto de Democracia y Derechos Humanos.

Sassòli, M. (2020). International Humanitarian Law and International Human Rights Law. En B. Saul \& D. Akande (eds.), The Oxford Guide to International Humanitarian Law. Oxford University Press.

Sivakumaran, S. (2012). The Law of Non-International Armed Conflict. Oxford University Press.

Skoknic, F. (s. f.). Paren las prensas: "extremistas" abatidos en "enfrentamientos". Los Casos de la Vicaría. http://www.casosvicaria. cl/temporada-dos/paren-las-prensas-extremistas-abatidos-enenfrentamientos/

Tribunal Penal Internacional para la ex Yugoslavia. (1995, 2 de octubre). Prosecutor v. Dusko Tadić.

Tribunal Penal Internacional para la ex Yugoslavia. (2008, 3 de abril). Prosecutor v. Ramush Haradinaj, Idriz Balaj and Lahi Brahimaj.

Tribunal Penal Internacional para la ex Yugoslavia. (2008, 10 de julio). Prosecutor v. Ljube Boškoski and Johan Tarčulovski.

Valdivia, V. (2006). Izquierdas y derechas en los años setenta: la reversión de la historia. En V. Valdivia, R. Álvarez \& J. Pinto (eds.), Su revolución contra nuestra revolución. Izquierdas y derechas en el Chile de Pinochet (1973-1981) (pp. 207-225). LOM Ediciones.

Vité, S. (2009). Typology of armed conflicts in international humanitarian law: legal concepts and actual situations. International Review of the Red Cross, 91(873), 69-94.

Werle, G. \& Jeßberger, F. (2014). Principles of International Criminal Law. Oxford University Press.

Wilmhurst, E. (2012). Introduction. En E. Wilmshurst (ed.), International Law and the Classification of Conflicts. Oxford University Press.

Wilmhurst, E. \& Breau, S. (eds.) (2007). Perspectives on the ICRC study on customary international humanitarian law. Cambridge University Press.

Zalaquett, J. (2007). El Caso Almonacid. La Noción de una Obligación Imperativa de Derecho Internacional de Enjuiciar Ciertos Crímenes y la Jurisprudencia Interamericana sobre Leyes de Impunidad. Anuario de Derechos Humanos, 3, 183-194. (40) 